\title{
Cephalopods in neuroscience: regulations, research and the 3Rs
}

\author{
Graziano Fiorito $\cdot$ Andrea Affuso $\cdot$ David B. Anderson $\cdot$ Jennifer Basil $\cdot$ Laure Bonnaud $\cdot$ Giovanni Botta \\ Alison Cole • Livia D'Angelo • Paolo De Girolamo • Ngaire Dennison • Ludovic Dickel • Anna Di Cosmo •

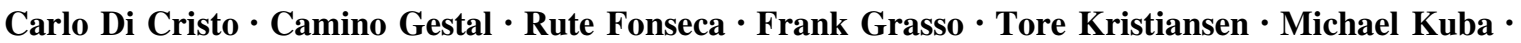 \\ Fulvio Maffucci - Arianna Manciocco · Felix Christopher Mark · Daniela Melillo · Daniel Osorio · \\ Anna Palumbo $\cdot$ Kerry Perkins $\cdot$ Giovanna Ponte $\cdot$ Marcello Raspa $\cdot$ Nadav Shashar · Jane Smith • \\ David Smith $\cdot$ António Sykes $\cdot$ Roger Villanueva $\cdot$ Nathan Tublitz $\cdot$ Letizia Zullo $\cdot$ Paul Andrews
}

Received: 27 July 2013 / Accepted: 8 November 2013/Published online: 3 January 2014

(C) The Author(s) 2013. This article is published with open access at Springerlink.com

\begin{abstract}
Cephalopods have been utilised in neuroscience research for more than 100 years particularly because of their phenotypic plasticity, complex and centralised nervous system, tractability for studies of learning and cellular mechanisms of memory (e.g. long-term potentiation) and anatomical features facilitating physiological studies (e.g. squid giant axon and synapse). On 1 January 2013, research using any of the about 700 extant species of "live cephalopods" became regulated within the European Union by Directive 2010/63/EU on the "Protection of Animals used for Scientific Purposes", giving cephalopods the same EU legal protection as previously afforded only to vertebrates. The Directive has a number of implications, particularly for neuroscience research. These include: (1) projects will need justification, authorisation from local
\end{abstract}

Graziano Fiorito, Jennifer Basil, Frank Grasso, Michael Kuba, Nadav Shashar and Paul Andrews have contributed equally to this work.

Disclaimer Cephalopod research, housing and mantainace is an often controversial and little studied subject; therefore, not all the authors and participants of the meeting necessarily agree with all points raised in the present paper.

G. Fiorito - A. Affuso - F. Maffucci - D. Melillo - A. Palumbo

Stazione Zoologica Anton Dohrn, Villa Comunale, Naples, Italy

G. Fiorito $(\varangle) \cdot$ G. Ponte $\cdot$ P. Andrews

Associazione Cephalopod Research 'CephRes', ONLUS,

Via dei Fiorentini 21, 80133 Naples, Italy

e-mail: cephres@cephalopodresearch.org

\section{A. Affuso}

Animal Model Facility, BIOGEM SCARL,

Via Camporeale Area PIP, Ariano Irpino, AV, Italy

D. B. Anderson

Midlothian Innovation Centre, Pentland Management Systems,

Pentlandfield, Roslin EH25 9RE, UK competent authorities, and be subject to review including a harm-benefit assessment and adherence to the 3Rs principles (Replacement, Refinement and Reduction). (2) To support project evaluation and compliance with the new EU law, guidelines specific to cephalopods will need to be developed, covering capture, transport, handling, housing, care, maintenance, health monitoring, humane anaesthesia, analgesia and euthanasia. (3) Objective criteria need to be developed to identify signs of pain, suffering, distress and lasting harm particularly in the context of their induction by an experimental procedure. Despite diversity of views existing on some of these topics, this paper reviews the above topics and describes the approaches being taken by the cephalopod research community (represented by the authorship) to produce "guidelines" and the potential contribution of neuroscience research to cephalopod welfare.

Keywords Cephalopods · Directive2010/63/EU · Animal welfare $\cdot 3$ Rs $\cdot$ Neuroscience

\author{
J. Basil \\ Biology Department, CUNY Graduate Center, Brooklyn \\ College, 2900 Bedford Avenue, Brooklyn, NY 11210, USA \\ L. Bonnaud \\ Muséum National d'Histoire Naturelle, DMPA, Lab. BOREA, \\ UMR MNHN CNRS 7208-IRD 207-UPMC, Paris Cedex, France \\ L. Bonnaud \\ Université Paris Diderot, Sorbonne Paris Cité, Paris, France \\ G. Botta \\ Ministero della Salute, Via G. Ribotta 5, 00144 Rome, Italy
}




\section{Introduction}

Cephalopods are a numerically small but significant taxon of invertebrates (phylum Mollusca) whose richness of behavioural capabilities (Borrelli and Fiorito 2008) fascinate the public and researchers alike, but that also represent a very important resource for human consumption (Jereb et al. 2005). The class Cephalopoda is considered the most complex one in the phylum Mollusca and arguably amongst all other invertebrate phyla as reflected in the use of the term "advanced invertebrate" or "exceptional invertebrate class" (sensu Zullo and Hochner 2011). It includes exclusively marine living species considered to have rivaled fishes during evolution (e.g. Packard 1972; but see also Kröger et al. 2011). Cephalopods demonstrate a refined and extraordinary ability to adapt their morphology (Kröger et al. 2011) and behavioural repertoire to their niche; this may have contributed greatly to their success (Hochner et al. 2006; Hochner 2008, 2012; Borrelli and Fiorito 2008). Amongst the several notable expressions of phenotypic plasticity in cephalopods (Hanlon and Messenger 1996; see also Barbato et al. 2007) is the capability to display environmentally cued phenotypes, i.e. body patterns (Borrelli et al. 2006). The complex behavioural and learning capabilities of cephalopods (Hanlon and Messenger 1996; Borrelli and Fiorito 2008; Huffard 2013) correspond to a highly sophisticated nervous system that appears to be correlated with their lifestyle (Nixon and Young 2003; Borrelli 2007). The flexibility of the behavioural repertoire of cephalopods is supported by evident cellular and synaptic

\section{A. Cole}

BIOGEM SCARL, Via Camporeale Area PIP,

Ariano Irpino, AV, Italy

\section{D'Angelo · P. De Girolamo}

Department of Veterinary Medicine and Animal Productions,

University of Naples Federico II, Naples, Italy

\section{N. Dennison}

Home Office, Animals in Science Regulation Unit,

Dundee DD1 9WW, Scotland, UK

\section{Dickel}

Groupe Mémoire et Plasticité Comportementale, EA4259, GdR CNRS 2822 Ethology, University of Caen Basse-Normandy, Caen, France

\author{
A. Di Cosmo \\ Department of Biology, University of Naples Federico II, \\ Naples, Italy \\ C. Di Cristo \\ Department of Biological and Environmental Sciences, \\ University of Sannio, Benevento, Italy \\ C. Gestal \\ Instituto de Investigaciones Marinas (IIM-CSIC), Vigo, Spain
}

plasticity at the level of the central and peripheral nervous system and of the neuromuscular junctions (review in Brown and Piscopo 2013). Cephalopods are well known amongst neuroscientists for their contribution to fundamental understanding of the nervous system (Young 1985; Abbott et al. 1995; but see also Brown and Piscopo 2013).

This paper is prompted by the recent inclusion of "all live cephalopods" in Directive 2010/63/EU that regulates the use of animals for scientific purposes (European Parliament and Council of the European Union 2010).

Regulation of scientific uses of cephalopods

National legislation regulating experimentation on living animals began to appear in several European countries in the late nineteenth century and made a division between vertebrates and invertebrates, with only vertebrates being regulated (i.e.: United Kingdom, 1876; Germany, 1883; Denmark, 1891; see Smith et al. 2013 for references). ${ }^{1}$

One species of cephalopod, Octopus vulgaris, was included in a revision of the UK legislation (Animals [Scientific Procedures] Act 1986), but no studies have ever been conducted under the legislation. Cephalopods have been included in various national codes of practice and legislation covering research in several countries outside the EU, for example: Canada, 1991; New Zealand, 1999; Australia, 2004; Switzerland, 2011; Norway, 2011; see Smith et al. (2013) for details and references.

Animal experimentation involving all vertebrates has been regulated at EU level since 1986 (Directive 86/609/

\author{
R. Fonseca \\ Center for GeoGenetics, University of Copenhagen, \\ 1350 Copenhagen, Denmark \\ F. Grasso \\ Department of Psychology, BioMimetic and Cognitive Robotics, \\ Brooklyn College, CUNY, Brooklyn, NY 11210, USA \\ T. Kristiansen \\ Institute of Marine Research, 5817 Bergen, Norway \\ M. Kuba \\ Max Planck Institute for Brain Research, \\ 60438 Frankfurt, Germany
}

\footnotetext{
1 The vertebrate species commonly covered were those utilised in experiments (primarily physiology) at the time (e.g. frogs, cats, dogs). The wording of the UK 1876 Cruelty to Animals Act perhaps gives an additional insight into the basis for "the division" between invertebrates and vertebrates. The Act permits "the advancement of new discovery of physiological knowledge by experiments calculated to give pain" (our italics), implying that the authors of the Act may have taken the view that whilst vertebrates may experience pain invertebrates do not (but see Fiorito 1986; and Andrews 2011a; Andrews et al. 2013 for details).
} 
EEC) and Directive 2010/63/EU (European Parliament and Council of the European Union 2010), which we will refer to here as the "Directive" is a major revision intended to make the regulation "more stringent and transparent" as well as recognising advances in research techniques, improved understanding and assessment of animal welfare (see: Broom 1991a, b, 2011 for an introduction to the issues) and developments in ethical review of animal experimentation (Smith et al. 2013) particularly in relation to invertebrates (Mather and Anderson 2007; Moltschaniwskyj et al. 2007; Horvath et al. 2013). The Directive also places particular emphasis on application of the "3Rs" principles of Replacement, Reduction and Refinement formulated by Russell and Burch (1959) and discussed in detail below in relation to neuroscience research.

For invertebrate research in the EU, Directive 2010/63/ EU which implemented on 1 January 2013 marks a paradigm shift by covering the use of an entire class of Molluscs, namely "live cephalopods" (i.e. hatched juveniles and adults) in the legislation covering experimental procedures likely to cause pain, suffering, distress or lasting harm (EFSA Panel on Animal Health and Welfare 2005; European Parliament and Council of the European Union 2010; Smith et al. 2013). This means that, under the Directive and transposed national laws, cephalopods have the same legal status as vertebrates in relation to their experimental use in research and testing (Smith et al. 2013).

It should be noted that drafts of the Directive also included decapod Crustacea (e.g. crabs, lobsters). Although

\footnotetext{
A. Manciocco

Institute of Cognitive Sciences and Technologies, CNR,

Via Aldovrandi 16b, Rome, Italy

F. C. Mark

Integrative Ecophysiology, Alfred Wegener Institute for Polar and Marine Research, Bremerhaven, Germany

D. Osorio · K. Perkins

School of Life Sciences, University of Sussex, Brighton,

E Sussex BN1 9RH, UK

\section{Raspa}

European Mouse Mutant Archive (CNR-EMMA), Consiglio

Nazionale delle Ricerche, Campus A. Buzzati-Traverso, Viale E.

Ramarini, 32, 00015 Monterotondo Scalo, Roma, Italy

\section{N. Shashar}

Department of Life Sciences, Ben-Gurion University of the

Negev, Eilat Campus, 84105 Beer-Sheva, Israel

J. Smith

The Boyd Group, Hereford, UK

D. Smith

Federation for Laboratory Animal Science Associations

(FELASA), London, UK
}

decapod crustaceans were not included in the adopted Directive, it is likely that this issue will be revisited because of the continuing debate about their pain perception (Gherardi 2009; Magee and Elwood 2013; Horvath et al. 2013) and also because as was the case with cephalopods there is interest in this issue from animal welfare and animal rights groups (Advocates for Animals 2005).

The decision to include cephalopods was based primarily upon the recommendations of a scientific panel which concluded that there was "scientific evidence of their ability to experience pain, suffering, distress and lasting harm" (i.e. PSLDH; Directive 2010/63/EU: Recital 8, European Parliament and Council of the European Union 2010). However, note that this view is not universally shared by the global research community. In essence, much of the evidence for inclusion of cephalopods in the Directive is based upon various aspects of neuroscience research on cephalopods and the criteria used, as well as additional recent studies, are reviewed by Andrews et al. (2013).

It is anticipated that the Directive will provide a stimulus to cephalopod neuroscience research, as ensuring the highest welfare standards requires answers to a number of questions some of which are summarised in Table 1.

The Directive will impact upon scientific work using any of the approximately 700 extant species of cephalopods, but in practice within the EU the species most commonly used are the coleoid cephalopods: the cuttlefish Sepia officinalis; the squids Loligo vulgaris and Loligo forbesi; and the octopuses $O$. vulgaris, Eledone cirrhosa and Eledone

A. Sykes

Centre of Marine Sciences (CCMAR), Universidade do Algarve, 8005-139 Faro, Portugal

R. Villanueva

Renewable Marine Resources Department,

Institut de Ciències del Mar (CSIC), Barcelona, Spain

N. Tublitz

Department of Biology, University of Oregon,

Eugene, OR 97403, USA

L. Zullo

Department of Neuroscience and Brain Technologies,

Istituto Italiano di Tecnologia, Genoa, Italy

P. Andrews

Division of Biomedical Sciences, St George's University of

London, Cranmer Terrace, London SW17 0RE, UK 
Table 1 Possible areas of biological and neuroscience research expected to contribute to increasing knowledge of cephalopod welfare as stimulated by Directive 2010/63/EU

Optimal conditions of care and maintenance of animals also aimed to increase well-being

Evidence of the capacity for cephalopods to experience pain

Search for receptors sensitive to noxious stimuli

Functional analysis of "brain centres"

Analysis of nervous pathways connecting the nociceptive system to higher "brain centres"

Search for receptors for opioid, cannabinoid and analgesic steroid substances

Studies on analgesia and animals' responses

Behavioural and functional analysis of animals' response to painful stimuli

Search of objective signs of pain, suffering and distress

Physiological indicators of pain

\section{Humane end points in cephalopod studies}

General anaesthesia for cephalopods

Establishment of objective criteria for assessing depth of general anaesthesia

Methods for maintenance of general anaesthesia and facilitation of recovery

Methods for production of local anaesthesia and systemic analgesia

Methods for humane killing

Physiological analysis and evaluation of stress, suffering or pain, including evaluation of biomarkers of immune response linked to diseases and distress

Noninvasive approaches to characterise physiological function of organs and systems and monitoring effects of experimental treatments

For review and further discussion see Andrews (2011a, b), Andrews et al. (2013) and Smith et al. (2013). See also: Borrelli and Fiorito (2008), Ponte and Fiorito (2011, 2013), Boal (2011), Margheri et al. (2011b), Ponte et al. (2013)

moschata. The shelled cephalopod Nautilus pompilius is also used occasionally but is imported from tropical waters.

Compliance with the new EU legislation will be challenging for many areas of cephalopod research, especially neuroscience; some concern has already been expressed regarding the applicability of "mammal-centric" regulations to cephalopods (Nosengo 2011). Yet, the legislation by itself is not aimed to be "mammal-centric", as the law applies equally to fish, amphibians and birds as well as mammals, and the principles are the same for all species!

\section{Some implications of the Directive for research on cephalopods}

The inclusion of cephalopods in the Directive has a number of implications for different groups:
1. Researchers All researchers who use cephalopods in their research will need to ascertain whether the intended experiments are covered by the Directive and if so an application will need to be submitted to the appropriate National Competent Authority (NCA; $;^{2}$ e.g. Home Office in the UK; Ministère de l'Enseignement Supérieur et de la Recherche in France; Ministero della Salute in Italy) and approval obtained prior to starting the project. The authorisation process involves impartial evaluation of the project by the NCA including examination of the purpose of the research procedures (permitted purposes are listed in Article 5 of the Directive), compliance with 3 Rs, severity classification of procedures and a harm-benefit analysis of the project (Voipio et al. 2004; for details and examples see: Smith et al. 2013). Researchers should consult their NCA to obtain details of the authorisation process as although the principles are common throughout the $\mathrm{EU}$, the way in which the Directive is transposed into national legislation may differ. It should also be noted that in addition to covering the experiments themselves, the Directive also regulates the place where experiments are undertaken, the standards of housing and care of animals used for research and methods of euthanasia. Researchers will also need to ensure that their project is authorised and that their whole team is familiar with the national law covering their experiments are appropriately trained and competent to perform the procedures (Article 23 of the Directive) and, if required by the national legislation, that the project and personnel are covered by appropriate licences (e.g. in the UK Home Office Project and Personal Licences). A checklist of what is needed in the case of conducting cephalopod research in the EU is summarised in Smith et al. (2013).

2. Animal technologists, veterinarians and regulators The Directive places the care and welfare within a legal framework requiring documented monitoring and compliance. Research on cephalopods, under the Directive, is likely to be performed in the same places where research is currently undertaken, so those currently responsible for care and welfare will be hopefully familiar with the expected requirements. Nonetheless, it is likely that some training will be needed even for those familiar with maintenance of cephalopods in the laboratory. In addition, veterinarians or other suitable qualified experts with responsibility for laboratory animal facilities will need to become familiar with all aspects of health and welfare of the cephalopod species in their care. Although there

\footnotetext{
${ }^{2}$ A list of NCA is available at http://ec.europa.eu/environment/ chemicals/lab_animals/ms_en.htm.
} 
are reviews covering cephalopod health (e.g.: Boletzky and Hanlon 1983; Hochberg 1990; Hanlon and Forsythe 1990a, b; Boyle 1991; Castellanos-Martinez and Gestal 2013), there are few aquatic medicine courses covering invertebrates (see for example: VirginiaMaryland Regional College of Veterinary Medicine, http://www.vetmed.vt.edu/research/aquatic/education. html).

One aspect of monitoring compliance with the Directive involves "regular inspections" of establishments, of which "an appropriate proportion" is to be carried out "without prior warning" (Directive Article 34). Monitoring may involve inspection of the place where the animals are kept, observations of procedures and inspection of experimental records. The records must include the source of the animals, whether they were purpose bred, what they were used for and by whom, and their fate at the end of the study (Directive Article 30). Those responsible for monitoring compliance with the Directive will need training to become familiar with this newly regulated class of animal.

3. Funders Most grant funding agencies and charities already require that grant applications involving research on vertebrates certify that, if required, appropriate authorisation (normally including "ethical" review) to conduct the proposed studies is in place. As cephalopods are now covered by the same legislation as vertebrates, grants involving particular types of research concerning their regulated use will need to ensure that the proposed studies comply with the Directive and any national Codes of Practice related to care and welfare.

4. Journal editors and reviewers The editors and reviewers of Journals will need to be made aware of the change in the regulation within the EU to ensure that papers submitted for publication if appropriate make reference to compliance with the Directive. This may be difficult for a short period as although the Directive was implemented on 1 January 2013, some EU states have not yet transposed it into national legislation (http://ec.europa.eu/environment/chemicals/lab_animals/ transposition_en.htm). Although not part of the Directive, several journals (e.g. Nature, PLoS $)^{3}$ have voluntary adopted the ARRIVE (Animal Research: Reporting of in vivo Experiments: http://www.nc3rs.org.uk/page. asp?id=1357) guidelines for reporting experiment (Kilkenny et al. 2010). These guidelines provide checklists of information that should be included in published

\footnotetext{
$\overline{3}$ For an updated list see Journals that have incorporated ARRIVE in their Instructions for Authors at: http://www.nc3rs.org.uk/page. asp?id=1796.
}

papers, particularly in the methods sections. Whilst many papers involving cephalopods already contain much of this information, key information is lacking in others. For example, only in the $40 \%$ of papers published in the $2010(n=65$; source WoK: ISI Web of Knowledge), mention the conditions in which cephalopods are maintained. However, only half of those (13 out 26 papers) provide details on tank and lighting. Further analysis reveals that for the five cases in which octopuses were utilised, tanks ranged from 200 to $7,000 \mathrm{~L}$ and for cuttlefishes $(n=7)$ a wider range of tank sizes was utilised (from 30 to 20,000 L). It is remarkable that a justification for such a diversity of approach for accommodating animals is missing in the papers. Finally, no indication of the stocking density of animals is provided in the great majority of studies here considered.

The lack of such information makes it difficult to undertake systematic analysis of housing conditions in order to derive guidelines reflecting the consensus in the literature. In addition, lack of critical information on sex, body weight, feeding, tank size, lighting, handling and euthanasia methodology can compromise assessment of results. Based upon studies in vertebrates, the outcome of neuroscience studies, and in particular studies of behaviour in cephalopods, is most likely to be sensitive to environmental factors.

5. The public Although cephalopods are frequently portrayed as creatures of nightmares in films and literature (e.g.: Muntz 1995; Ellis 1998), people are nevertheless fascinated by these animals in display aquaria and they make frequent appearances in natural history documentaries and the media. In contrast to mice, rats and rabbits, the public do not make an immediate association between cephalopods and "animal experimentation", but this may change as the knowledge of their inclusion in the Directive becomes more widely known and researchers should be aware that their studies may come under public and media scrutiny.

\section{Neuroscience research and the impact of the Directive}

Cephalopods are a large group of marine predators whose major aspects of biology, behaviour, and ecology provide a backdrop against which their neurobiology can be interpreted. Special features of their reproduction (Rocha et al. 2001), camouflage, motor control, memory, learning, and behavioural ecology may be considered as special cases of convergent evolution with vertebrates (Packard 1972; Borrelli and Fiorito 2008; Huffard 2013). 
Table 2 A selected summary of cephalopod neuroscience and neurobehavioural research [for review see also: Borrelli and Fiorito (2008), Brown and Piscopo (2013), Huffard (2013)]

\section{Squid giant axon and giant synapse}

Physiology of resting membrane potential and action potential [consider also the Nobel Prize to Eccles (Hodgkin and Huxley 1952)]

Giant axon-Schwann cell signalling

Physiology and pharmacology of synaptic transmission

Axoplasmic transport

Consider also recent studies on

The effect of mutant SOD1 implicated in Lou Gehrig disease in humans

Effect of human tau-protein implicated in Alzheimer's disease

Relevant references: Young (1938), Bullock (1948), Hodgkin and Huxley (1952), Bloedel et al. (1966), Coles and Abbott (1996), Moreno et al. (2011), Song et al. (2012)

\section{Behavioural studies and the search for their} neural correlates

Behavioural plasticity, learning and memory

Sleep-like states

Consciousness

Physiology and pharmacology of long-term potentiation (LTP)

Relevant references: Sanders (1975), Fiorito et al. (1990), Young (1991, 1995), Fiorito and Scotto (1992), Robertson et al. (1994, 1995, 1996), Fiorito and Chichery (1995), Boal 1996, Boal and Gonzalez (1998), Boal and Golden (1999), Boal et al. (2000), Agin et al. (2001), Vinogradova et al. (2002), Agin et al. (2003), Hochner et al. (2003, 2006), Karson et al. (2003), Darmaillacq et al. (2004, 2006), Boal (2006), Agin et al. (2006), Brown et al. (2006), Langridge et al. (2007), Hochner (2008), Shomrat et al. (2008, 2010), Mather (2008), Edelman and Seth (2009), Zullo et al. (2009), Zylinski et al. (2011), Shomrat et al. (2011), Tricarico et al. (2011), Zullo and Hochner (2011), Edelman (2011), Osorio and Zylinski (2011), Gutnick et al. (2011a, b), Josef et al. (2012), Hochner (2012), Frank et al. (2012)

\section{Neurotransmitters (sensu lato)}

Relevant references: Florey (1963), Loe and Florey (1966), Florey and Winesdorfer (1968), Tansey (1978, 1979), Budelmann and Bonn (1982), Williamson (1989), Cornwell et al. (1993), Messenger (1996), Palumbo et al. (1999), Loi and Tublitz (2000), Lima et al. (2003), Di Cosmo et al. (2004, 2006, 2007), Fiore et al. (2004), Scheinker et al. (2005), Di Cristo et al. (2007), Boyer et al. (2007), Wollesen et al. (2008, 2010a, b, 2012), Bardou et al. (2009, 2010), Shomrat et al. (2010), Ponte (2012), Conti et al. (2013)

\section{Nociception}

Relevant references: Crook and Walters (2011), Crook et al. (2011, 2013), Hague et al. (2013), Andrews et al. (2013), but see also: Wells et al. (1965), Wells (1978), Hanlon and Messenger (1996), Mather and Anderson (2007)

\section{Regeneration}

Regeneration of appendages following damage (wild and experimental)

Nerve regrowth

Relevant references: Lange (1920), Sereni and Young (1932), Sanders and Young (1974), Féral (1988), Rohrbach and Schmidtberg (2006), Florini et al. (2011), Fossati et al. (2013)
Table 2 continued

\section{Neuromotor control}

Motor and sensory control of arm movements

Arm use preference and functioning (including suckers)

Octopus arm as a bio-inspired robotic model

Control of chromatophores and body patterning

Relevant references: Kier (1982, 1985, 1991), Kier and Smith (1985), Hanlon and Messenger (1996), Kier and VanLeeuwen (1997), Mather (1998), Loi and Tublitz (2000), Messenger (2001), Sumbre et al. (2001, 2005, 2006), Borrelli et al. (2006), Gutfreund et al. (2006), Byrne et al. (2006a, b), Grasso and Setlur (2007), Barbato et al. (2007), Grasso (2008), Kier and Schachat (2008), Zullo et al. (2009), Mattiello et al. (2010), Calisti et al. (2011), Margheri et al. (2011a, b, 2012), Mazzolai et al. (2012), Laschi et al. (2012)

\section{Physiology of the sensory systems}

Visual and chemo-tactile systems

Statocyst and oculomotor systems

Relevant references: Bullock (1965), Williamson (1986, 1989, 1995), Budelmann (1995), Abbott et al. (1995), Lucero and Gilly (1995), Budelmann et al. (1997), Williamson and Chrachri (2004)

Development and functional organisation of the "brain" and muscles

Relevant references: Young (1991, 1995), Gutfreund et al. (1996), Shigeno et al. (2001a, b, 2008a, b), Callaerts et al. (2002), Shigeno and Yamamoto (2002), Lee et al. (2003), Hartmann et al. (2003), Nixon and Young (2003), Grimaldi et al. (2004), Borrelli (2007), Navet et al. (2008), Lee et al. (2009), Baratte and Bonnaud (2009), Navet et al. (2009), Wollesen et al. (2009), Zullo et al. (2009), Zullo and Hochner (2011), Hochner (2012), Mattiello et al. (2012)

An annotated bibliography on classical contributions to cephalopod' biology and physiology is also provided by Ponte et al. (2013). References to relevant studies included are given as examples

Neuroscience research involving brain and behaviour is particularly prominent because of the perceived status of cephalopods as "advanced invertebrates". Cephalopods are model organisms for a diverse range of neuroscience areas, and their anatomical features provide unique opportunities for research (see examples in Table 2). Neuroscience research studies may be particularly impacted by the Directive as they cover a diversity of experimental techniques ("procedures") which are often invasive and may cause pain, suffering, distress and lasting harm. This aspect is discussed in detail hereunder with examples of the types of study likely to fall within the scope of the Directive and which will need to be authorised by the appropriate national competent authority. Although researchers should be familiar with all the requirements of the Directive in relation to routine care and welfare, it is the aspects of the Directive covering procedures and their impact upon the health and welfare of the animal that are likely to have the greatest impact upon their use in research. 


\section{Care and welfare of cephalopods in neuroscience research and the need for guidelines}

The inclusion of all live cephalopods (i.e. larval and adult forms) in the new EU Directive has a number of practical implications for those undertaking research involving cephalopods, irrespective of the subject area. Guidelines for the general care and welfare for vertebrate laboratory species such as mammals (Sikes and Gannon 2011) and fishes (DeTolla et al. 1995; Hawkins et al. 2011a) are well developed, and specific guidelines are available for the welfare of vertebrates used in particular types of research such as cancer (Workman et al. 2010). For vertebrates in general and mammals specifically, objective criteria for identification and assessment of pain, suffering, distress and lasting harm are well researched (e.g.: Morton and Griffiths 1985; Bateson 1991) and protocols for surgery, anaesthesia, analgesia and humane euthanasia established. However, for cephalopods such knowledge is relatively rudimentary and maybe further hampered by lack of specific veterinary expertise; as in contrast to vertebrates, cephalopods are not common companion animals, although they are often found in display aquaria and knowledge gained in this setting is making a useful contribution to understanding their general welfare requirements.

The Directive is likely to stimulate research in the above areas so as to facilitate development of evidence-based guidelines for optimal care and welfare (Moltschaniwskyj et al. 2007; Louhimies 2011; see for example: Andrews 2011a, b; Goncalves et al. 2012; Sykes et al. 2012; Andrews et al. 2013; Smith et al. 2013).

The text of the Directive does not provide specific guidance on the above aspects for cephalopods, and at present, there are no national codes of practice for care and use of cephalopods under the terms of the Directive. In view of this, the cephalopod research community initiated a project to develop guidelines for the Care and Welfare of Cephalopods in Research. This project is an initiative ${ }^{4}$ between the Federation of European Laboratory Animal Science Association (FELASA: www.felasa.eu), the Boyd Group (http://www.boyd-group.demon.co.uk/) and CephRes (www.cephalopodresearch.org). The guidelines are being developed based upon structured discussions amongst 30 active cephalopod researchers drawn from 26 research institutes in 11 countries including from outside the EU. The discussions also included national and EU legislators and regulators, as well as researchers with expertise in vertebrate animal welfare (i.e. Giovanni Botta, Italy; Paolo De Girolamo, Italy; Ngaire Dennison, UK;

\footnotetext{
${ }^{4}$ Developing guidelines for the care and welfare of Cephalopods under European directive 2010/63/EU. Available at: http://www. felasa.eu/announcements/felasa-collaboration-on-cephalopods.
}

Tore Kristiansen, Norway; Marcello Raspa, Italy; Jane Smith, UK; David Smith, UK). Some of the main points arising from these discussions, with particular impact upon neuroscience research, are discussed below. It must be emphasised that these only provide an overview, and there are still many areas of contention. More detailed reviews of specific aspects and species should be consulted for more practical information.

Table 3 summarises some of the main reviews and topics in this area. However, given that there are more than 700 known living species of cephalopods of which a wide variety are used for scientific purposes, care should be taken to meet the particular requirements of individual species involved in experiments or other scientific procedures. Species-specific guidelines will need to be developed, and for many aspects of care and welfare, this will require research, but here we focus on the more generic

Table 3 Summary of resources relevant to implementation and compliance with specific aspects of Directive 2010/63/EU in relation to cephalopods

\begin{tabular}{lc}
\hline Area covered by the Directive & References \\
\hline $\begin{array}{l}\text { Biology including normal } \\
\text { behaviour and physiology }\end{array}$ & Bullock (1965), Wells (1962, \\
& 1978), Hanlon and Messenger \\
& (1996), Norman (2000), Boyle \\
and Rodhouse (2005), Borrelli \\
et al. (2006), Boal (2011) \\
Overview of Directive & Smith et al. (2013)
\end{tabular}

requirements and project

("ethical") review

List of what needs to be done if you are a researcher

Ethics of cephalopod research and invertebrates in general

3 Rs principles in relation to cephalopod research including worked examples of project review

Various aspects of general maintenance, handling, rearing and culture of a number of cephalopod species

Pain, suffering and distress in cephalopods

Approaches to objective measurement of cephalopod health and welfare

General anaesthesia

Euthanasia
Mather and Anderson (2007), Moltschaniwskyj et al. (2007), Andrews (2011a), Horvath et al. (2013)

Smith et al. (2013)

Grimpe (1928), Walker et al. (1970), Boletzky and Hanlon (1983), Boal (2011), Sykes et al. (2012)

Crook and Walters (2011), Crook et al. (2011, 2013), Andrews et al. (2013)

Gunkel and Lewbart (2008), Pagano et al. (2011), Lewbart and Mosley (2012), Goncalves et al. (2012), Gleadall (2013), Andrews et al. (2013)

Boyle (1991), Demers et al. (2006), Andrews et al. (2013) 
issues relating to the cephalopod species most commonly used in the EU, as a baseline for future Guideline development.

\section{Care and welfare of cephalopods: an introduction}

This section discusses some of the key areas covered by the Directive and which we believe impact particularly upon neuroscience research involving cephalopods.

\section{Sources of animals}

Cephalopods used in research are currently commonly taken from the wild (for review on fishing methods see: Lane 1960; Boyle and Rodhouse 2005) mainly because of the difficulties of laboratory breeding of many but not all species. Recent exceptions are, for example, S. officinalis, Octopus bimaculoides, Euprymna scolopes (review in Albertin et al. 2012). However, the Directive (Article 9) prohibits capture in the wild unless an exemption has been granted by the NCA. In practice, this means that animals may still be obtained from the wild provided that this can be justified to the Competent Authority. In addition, capture must be undertaken by competent persons using methods which do not cause pain, suffering, distress or lasting harm.

Wild caught animals may be obtained from approved suppliers (including authorised laboratories specialising in cephalopod research or specialist importers as in the case of Nautilus), but they must also obtain approval for the capture from the NCA.

Depending upon the research project, one potential issue with using research animals from the wild is that it may be harder to ensure "standardised" groups of animals both within a study continuing over several years and to permit comparison between research groups in different locations. This inherent variability may lead to the use of a larger number of animals than in other studies to demonstrate statistically significant effects, particularly in behavioural studies, and this could become an issue in project evaluation and authorisation where factors taken into account include animal numbers (estimates may include power calculation) and experimental design (including statistical analysis) to ensure that the minimum number of animals are used to achieve the scientific objective (see instructions and citations included in Animal Behaviour 2012).

Transport, quarantine and acclimatisation

Transport of animals should be minimised, and where possible the researcher should travel to study the animals not vice versa. A solution is to transport eggs rather than animals (e.g. cuttlefish) and to culture these; however, as mentioned above, this is not possible for most cephalopod species. Transport of animals should always be in sea water. The levels of available oxygen and accumulation of metabolites in a limited volume are important considerations for transport of living cephalopods, as recommended in the classic work by Grimpe (1928).

When animals are transported, the potential impact upon their health and welfare will need to be assessed and careful consideration given to the time required for adaptation before experimentation. On arrival in the laboratory, all animals should be closely inspected for overt signs of illness and if necessary advice sought from the person with legal responsibility for the care of animals (e.g. veterinarian or other appropriately qualified expert) on action to be taken.

Quarantining the animals is good practice whether they come from the wild or an authorised breeder/supplier as it reduces the risk of introducing infectious agents or parasites that could spread to other animals. It also gives time for diseases to manifest before animals are assigned to a research project requiring long-term study.

Irrespective of their origin, animals will need some time to acclimatise to their novel home or experimental environment (review in: Grimpe 1928; Borrelli 2007; Borrelli and Fiorito 2008) before any experimental procedures can be contemplated, although the nature of the study may affect the duration of acclimatisation. Research is needed to identify objective measures of acclimatisation.

Acclimatisation also needs to be considered when moving animals from one tank to another within the laboratory especially if the animal has been moved out of water even for brief periods. For example, in E. cirrhosa Malham et al. (2002) showed that 5-min exposure to air produced a significant increase in plasma noradrenaline lasting up to $30 \mathrm{~min}$ and in reactive oxygen species lasting $2 \mathrm{~h}$. The experimenter should be aware of potential handling and relocation stress, and their possible impacts upon their study. For instance, the skin of cuttlefishes and squids is delicate and may be harmed if they are removed from the water with nets; nautiluses are particularly sensitive to exposure to air (J. Basil, personal communication), and this should be avoided if possible by transporting them in vessels containing sea water; for octopuses, it is acceptable to use wet nets with a fine mesh (but see Walker et al. 1970). Movement of animals should be minimised.

Environment and its control

\section{Water supply and quality}

As a minimum, sea water salinity, dissolved oxygen, $\mathrm{pH}$, nitrogenous compounds and temperature must be 
monitored and maintained within physiological ranges reported for each species.

Cephalopod housing systems currently are predominantly based on open systems where a continuous supply of fresh sea water from a nearby location is available. More recently, efficient and relatively easily maintained closed aquarium systems have been developed (Toonen 2003; Gutnick et al. 2011b). In open sea water systems, water flow and exchange should be high enough to maintain water quality comparable to natural conditions. In a closed system, sea water salinity, dissolved oxygen, $\mathrm{pH}$, nitrogenous compounds and temperature must be monitored and maintained within physiological ranges reported for each species.

Commercially available artificial seawater preparations are considered adequate and contain all the necessary substances and trace elements to keep cephalopods in good health (e.g. any mixture designed for marine invertebrates and corals but not fish is recommended). Trace elements, in particular strontium and calcium, should be monitored and added, if necessary.

Cephalopods are reported to accumulate (e.g.: Storelli et al. 2005; Seixas et al. 2005; Seixas and Pierce 2005; Raimundo et al. 2005; Napoleao et al. 2005; Raimundo and Vale 2008; Lacoue-Labarthe et al. 2008; Bustamante et al. 2008; Raimundo et al. 2009, 2010b; Pernice et al. 2009; Lourenco et al. 2009; Galitsopoulou et al. 2009; Pereira et al. 2009; Cirillo et al. 2010; Lacoue-Labarthe et al. 2012), and be sensitive to heavy metals (Raimundo et al. 2010a; de Polo and Scrimshaw 2012; Semedo et al. 2012), so care should be taken to ensure these are monitored and maintained within normal ambient ranges.

It is important to keep water and tanks clean of animal waste, uneaten food or inedible components (e.g. crab shells).

\section{Light requirements}

Photoperiod and light intensity should be maintained according to the natural living habits and possibly the geographical origin of the animal. A simulated dusk and dawn period is desirable. In the great majority of cases, cephalopods will adapt to changes in the lighting conditions in captivity (see for example: Fiorito et al. 1990; Borrelli 2007; Sykes et al. 2011). A number of studies have been carried out to analyse the circadian rhythm of several species (Houck 1982; Meisel et al. 2003, 2006; Brown et al. 2006; Frank et al. 2012). Recent studies also revealed an effect of light regimes on the growth of cuttlefish (Sykes et al. 2013). However, further studies are required to assess whether significant deviations in light intensity or photoperiod from the natural environment negatively impact animal welfare.
The use of a weak ambient light (e.g. moonlight lamp) or a specific red light illumination reduces the risk of disturbance when observation of the animal is required at night (e.g. Allen et al. 2010).

\section{Noise and vibration}

Recent evidence provides preliminary information on the impact of sound on cephalopods well-being (Guerra et al. 2007; André et al. 2011; Fewtrell and McCauley 2012). Noise, vibration and other sources of disturbance should be avoided; those originating from aquarium systems should be minimal, and preferably pumps and any other noise sources should be placed in a separate room.

Assessment and maintenance of health and welfare

Animals must be inspected at least once a day by a competent person, and a record kept of their conditions (Directive Annex III requirement). Signs of health and illness in cephalopods vary with species (for a review of possible signs due to diseases see: Hochberg 1990; Hanlon and Forsythe 1990a, b). Signs based upon appearance, behaviour and physiology which could be used as part of health monitoring programme are summarised below. Criteria for identification of well-being and illness are closely related to the development of signs of pain, suffering, distress and lasting harm (PSDLH) required for assessment of the impact of regulated procedures and development of humane end points ${ }^{5}$ for studies (Andrews 2011a; Andrews et al. 2013) including assessment of the effect of surgical procedures or drug treatments on the animals. Signs of illness and PSDLH also need to be capable of some quantification to assess their magnitude and duration for implementing humane end points and reporting data (a requirement under the Directive, for publication by the EU) on the actual severity of effects caused by procedures (e.g. mild, moderate, severe) in comparison with that anticipated at the time of project evaluation. This is an area requiring considerable research, and the criteria outlined below should be viewed as a starting point, from which more detailed guidance is being developed (for details see Andrews et al. 2013).

For each of the categories below, consideration needs to be given to grading the signs to link to the assessment of severity. For example, what degree of weight loss would be considered mild, moderate and severe?

\footnotetext{
5 I.e. the predetermined criteria which if they are reached result in termination of the procedure or require treatment/euthanasia of the animal.
} 
Indicators based on appearance of the animal

- Abnormal body colouration and body patterning, skin texture including swellings (bruising or oedema) and compromised skin integrity (erosion and ulceration); for examples see figures included in Hochberg (1990) and Hanlon and Forsythe (1990a, b). Skin lesions should always be closely monitored and if possible treated. For example, E. cirrhosa housed long term in the laboratory died within 2-4 days of the skin ulcerating (Boyle 1981, 1991).

- Abnormal morphology or damage to cuttlebone or shell.

- Abnormal body posture or position in the water column.

- Abnormal appearance as a result of body weight loss, possibly secondary to reduced food intake.

\section{Indicators based upon the behaviour of the animal}

- Reduced or absent food intake and a reluctance to feed or to attack (consider that reduced feeding during acclimatisation should be expected).

- Reduced or absent social interaction in social species and refusal or reluctance to leave a shelter in solitary housed species (e.g. O. vulgaris); lack of response to external stimuli or a sluggish response and in octopus a lack of natural curiosity.

- Stereotypic or repetitive behaviours.

- Reduced or excessive grooming and guarding behaviour of a body part.

- Abnormal motor or locomotor coordination.

- Autophagy or automutilation normally indicated by removal of one or more arms (Reimschuessel and Stoskopf 1990; Budelmann 1998).

- Excessive, uncontrolled or inappropriate inking.

\section{Clinical signs}

- Abnormal change (increase or decrease) in ventilation defined by rate, depth and coordination.

- Reduction in body weight over specific periods of time.

- Biomarkers such as phagocytes and catecholamines in the blood may increase due to several causes (e.g.: Malham et al. 1998a, b, 2002). ${ }^{6}$

\footnotetext{
${ }^{6}$ Note there is also a possibility of measuring faecal steroids (e.g. cortisol) as well as reproductive hormones (Larson and Anderson 2010) to assess welfare with the advantage that such techniques are noninvasive.
}

Causes of illness in cephalopods

Knowledge of the causes and diagnosis of illness (taken here to be any deviation from normal functionality) in cephalopods is rudimentary in comparison with fish and other vertebrates. The Directive's requirement for health monitoring should act as a stimulus to research in this area and in particular systematically collection, collation and exchange data. It will be important to distinguish between illness acquired in the wild, acquired in the laboratory and congenital defects. Causes of illness can be summarised under the following headings, but each cause requires detailed research, as do treatments.

1. Physical trauma This includes skin, shell, pen or gladius and cuttlebone damage during capture of wild caught animals or by collision with a transport or holding tank wall (Grimpe 1928; Boyle 1981). Bites and limb amputation are also commonly observed in wild caught animals (e.g. O. vulgaris, Florini et al. 2011) but may also occur during fighting, cannibalistic behaviour (Ibáñez and Keyl 2010) or by autophagy/ automutilation (Reimschuessel and Stoskopf 1990; Budelmann 1998).

2. Parasites, bacteria and viruses Host defence mechanisms in cephalopods have been reviewed by Ford (1992) and recently by Castellanos-Martinez and Gestal (2013). In the words of Boyle, "Cephalopods carry a wide variety of parasites and symbionts which include viruses, bacteria, fungi, sporozoans, ciliates, dicyemids (mesozoa), monogeneans, digeneans, cestodes, acanthocephalans, nematodes, polychaetes, hirudineans, branchiurians, copepods and isopods" (Boyle 1991, p. 133). However, there appear to be few data on the health impact (if any) of these various organisms, although it is likely that bacteria and viruses are causal agents of illness particularly in senescing animals with compromised defences (Anderson et al. 2002; Pascual et al. 2010). The cases provided below represent only few examples.

Bacteria have been isolated from skin lesions in octopus and squid (e.g.: Hanlon et al. 1984; Pascual et al. 2006) and infection of Octopus joubini with Vibrio alginolyticus induced skin ulceration in 2 days (as reported by Boyle 1991) and in E. cirrhosa a related Vibrio sp. (obtained from the diet) impaired skin would healing (Polglase et al. 1983; Bullock et al. 1987).

The gastrointestinal coccidian parasite Aggregata octopiana is found in $O$. vulgaris and produces malabsorption syndrome impacting growth (Castellanos-Martinez and Gestal 2011; but see also Castellanos-Martinez and Gestal 2013). A related organism 
(A. andresei) has been identified in the flying squid, Martialia hyadesi (Gestal et al. 2005). Larval nematodes including Ascaris and Anisakis (commonly found in fish) and larval and adult trematodes are reported in many cephalopod species (Hochberg 1990; Pascual and Hochberg 1996), but the health impact (if any) on the cephalopod is not known (for review see also Castellanos-Martinez and Gestal 2013).

The bacterium Vibrio fischeri has been studied extensively as it is a symbiont of the bobtail squid, E. scolopes (McFall-Ngai 1994; Nyholm et al. 2009; McFall-Ngai et al. 2010; Rader and Nyholm 2012; Collins et al. 2012; Nyholm and Graf 2012) and should not be considered as a disturbance.

3. Toxic substances As reviewed by Smith (2008) and Smith et al. (2008) toxic agents may originate from food and seawater. Food, particularly crustacea and bivalves, are a potential source of a number of neurotoxins including paralytic, diarrhoeic and neurotoxic shellfish toxins (Watkins et al. 2008; for review see for example: Wang 2008; see also Paredes et al. 2011). Although the clinical effects of these toxins on humans are clear, the impact (if any) on cephalopods is not known, but-in view of the number of brain behavioural studies in which cephalopods are usedstudies of the potential effect of the neurotoxic substances (including amnesia inducing toxins reported in cephalopods; e.g.: Costa et al. 2005; Costa and Pereira 2010; Lage et al. 2012; Braid et al. 2012) are needed to assess whether this could be a confounding factor in some research studies. Sea water may become toxic from excess levels of heavy metals and environmental pollutants. Little is known of the sensitivity of cephalopods to specific agents (e.g.: Raimundo et al. 2010a; Semedo et al. 2012). Measurements of antioxidant enzyme activity (catalase, superoxide dismutase, and glutathione $S$-transferases) in the digestive gland have been shown to be markers of oxidative stress induced by metal accumulation in O. vulgaris (Semedo et al. 2012). Recent studies have also shown that ingested nanoparticles induce immune responses in the octopus (Grimaldi et al. 2013). Sea water may also become toxic if oxygen, carbon dioxide, $\mathrm{pH}$ and nitrogenous waste products are outside normal limits (e.g.: Gutowska et al. 2010a, b; $\mathrm{Hu}$ et al. 2011) particularly if accompanied by elevated temperature.

Age estimation and senescence

Age estimation in cephalopods is essentially based upon direct methods (Semmens et al. 2004) and analysis of increments in internal structures (e.g.: Choe 1963; Bettencourt et al. 1996; Perez et al. 1996; Le Goff et al. 1998; Jackson and Moltschaniwskyj 1999; Bettencourt and Guerra 2000; Arkhipkin 2005; Hall et al. 2007; Ikeda and Kobayashi 2010; Hermosilla et al. 2010; Canali et al. 2011a, b; Lei et al. 2012; Arkhipkin and Shcherbich 2012; Raya et al. 2013). Further research is recommended to estimate age in cephalopods in vivo.

With age, cephalopods undergo the natural process of senescence, a process where the body appears to "shut down" in females after brooding (review in Rocha et al. 2001) and the animal begins to die. The clinical signs of animals in senescence include reduced or absent drive to eat, cloudy eyes and changed behaviour (Chichery and Chichery 1992a, b; Dumont et al. 1994; for review see also Anderson et al. 2002). Good record keeping of age may help to differentiate between animals that are affected by diseases or simply show signs of senescence.

The predictable onset of senescence in some species of cephalopods post-reproduction (Rocha et al. 2001; but see also Anderson et al. 2002) and the modulation of the process by the secretions from the optic gland (Wodinsky 1977) may make cephalopods a model for investigating the impact of senescence on the brain (see also: Chichery and Chichery 1992a, b; Dumont et al. 1994) and provide insights in neuroprotective mechanisms. Such studies would need to be justified in the project evaluation process and in particular the potential welfare issues regarding the care of senescent animals carefully considered (see Smith et al. 2013 for discussion).

\section{Housing and care}

Tank specification and location

Tank requirements (for review see also: Grimpe 1928; Hanlon et al. 1983; Boletzky and Hanlon 1983; Borrelli 2007) vary tremendously between species as do stocking densities. In some benthic species, the available bottom surface area is an important requirement, whilst in others the volume of water is of more relevance. Shape and size of tanks should accommodate the natural behaviour of the animals. For example, Nautiloids need to be provided with vertical space, but benthic cephalopods need to be given large surface areas rather than deep tanks, and pelagic species need sufficient space to swim. Smooth, curved walls are recommended at least for cuttlefish and squid. Annex III of the Directive requires that "All animals shall be provided with space of sufficient complexity to allow expression of a wide range of normal behaviour. They shall be given a degree of control and choice over their environment to reduce stress-induced behaviour". Animals 
should be provided with dens and shelters based upon their natural requirements. Use of gravel as a substrate for benthic species is highly recommended, but not mandatory. Environmental enrichment is already part of the best practice in cephalopod care for experimental purposes (e.g.: Fiorito et al. 1990; Mather and Anderson 1999; Dickel et al. 2000; Anderson and Wood 2001; Poirier et al. 2004; Borrelli 2007; Borrelli and Fiorito 2008; Boal 2011). It is interesting to note that in the classic work by Grimpe (1928) gravel, pebbles and stones are recommended to facilitate self-construction of a refuge by animals. In addition, other species, such as medium-sized sea stars, should be accommodated in the tanks to facilitate reduction in remains of food and faeces (Grimpe 1928). This would provide the enriched type of environment considered to be good welfare practice.

Cephalopods can be kept in shared water systems and rooms with different cephalopods species or other marine organisms. In principle, there is no need for separate rooms for experimental treatments and housing, but this will depend upon the type of study. For example, it is strongly recommended that a standardised dedicated room is used for behavioural experiments, and it is not good practice to perform surgical procedures and euthanasia in the same room where animals are housed. Moreover, animals subjected to surgical lesions should not be placed in a tank where there is a possibility that any chemical signal can be detected by un-operated animals.

Note that Directive Annex III, section A, includes general requirements pertaining to all species and also section $\mathrm{B}$, for fish, where most principles might also apply to cephalopods.

\section{Animal stocking}

Solitary animals (e.g. O. vulgaris) should be kept separately. Annex III of the Directive states that social animals must be socially housed in stable groups of compatible individuals (e.g. squids), but interactions should be monitored and animals separated if there is evidence of noncompatibility. Some animals such as Nautilus are primarily solitary in the wild, but may be housed together at low densities. The social structures of many species (e.g. S. officinalis) are not yet known, but captive bred European cuttlefish adults, as well as hatchling and young of all sources can be kept in groups (A. Sykes, pers. communication).

Routine animal care and maintenance

Animal care includes routine maintenance, husbandry, and animal handling. Handling procedures should be standardised within the laboratory (and field) to minimise experimental variability produced by different handlers, also taking into account that some animals may learn to anticipate handling procedures (Boycott 1954). As with any live animal, handling and human interaction should be kept to the minimum needed to meet daily care and experimental requirements, standardised and performed by trained staff only, to minimise stress. Handling and all human interactions should be recorded, as the amount, frequency and nature of the interactions can influence husbandry and the outcome of experiments (for a general review see: Davis and Balfour 1992). For octopuses, the effects of rough handling on the skin may not be apparent until several days (Wells 1962), and as mentioned above, skin lesions may be fatal (as reviewed in Boyle 1991) so this could have major consequences if the animal had been assigned to a study requiring long-term survival. Even for commonly used laboratory mammals, the effects of different handling techniques are still being discovered; for example, Hurst and West (2010) compared commonly used techniques of handling laboratory mice and showed marked differences in biomarkers of anxiety. For cephalopods, optimal handling protocols need to be identified for each species to minimise adverse effects, which can be a confounding factor in experiments.

\section{Feeding}

Feeding regimes should fit the lifestyle, natural diet, and developmental stages of the animals (see reviews in: Boletzky and Hanlon 1983; Borrelli 2007; Sykes et al. 2011, 2012). Cephalopods are carnivorous and, with the exception of the Nautilus, are predatory, and therefore, the use of live food can be essential, although may require justification (Smith et al. 2013). There are many examples of species and life stages where live prey is the only food accepted, and the benefits outweigh the risk of disease from the food. Efforts are underway to develop artificial diets. Daily feeding is common practice, and higher frequencies might be needed for young animals. Over feeding is preferred as long as excess food is removed in a time frame fitting the feeding habits of the species (Oestmann et al. 1997) and does not overwhelm the capacity of the filter system of the tank. Cuttlefish and squid are especially sensitive to lack of food; dead food can be used as alternative to live in some species (e.g.: Domingues et al. 2004; Ferreira et al. 2010).

Research is needed to identify optimal nutritional requirements that ensure health and welfare of each of the common laboratory species of cephalopod at key life stages. In addition, studies are needed to understand the physiological impact of a reduction in food intake because of illness, as a consequence of a surgical procedure or pharmacological intervention and as part of a training protocol for example when food may be used as a positive 
reinforcement. The impact of a particular experimental protocol upon food intake is likely to be a key question in harm-benefit evaluation of a project because of the high metabolic rate of cephalopods.

\section{Identification and marking techniques}

Most studies identify animals using individual housing, but some studies are done with groups of animals. In general, marking soft parts of cephalopods may have a deleterious effect on health and welfare and should be avoided. When scientifically necessary, individual marking may be performed, under anaesthesia, using for example fluorescent elastomer tags (Zeeh and Wood 2009; e.g. Sepioteuthis sp.: Ikeda et al. 2009; e.g. Octopus sp.: Barry et al. 2011; Brewer and Norcross 2012) or integrated archival tags including implanted microchips (in O. vulgaris: Estefanell et al. 2011; in S. officinalis: Wearmouth et al. 2013). For Nautilus, individual shell marking is preferred and can be done without anaesthesia (J. Basil, pers. communication).

In non-shelled cephalopods, there have been some reports of the use of unique natural patterns of individual animals as a means of identification (Huffard et al. 2008). The application of noninvasive methods for identification of individuals is important in the interests of animal welfare.

\section{Procedures}

A procedure within the Directive (Article 3,1) is defined as "Any use, invasive or noninvasive, of an animal for experimental or other scientific purposes, with known or unknown outcome, or educational purposes, which may cause the animal a level of pain, suffering, distress or lasting harm equivalent to, or higher than, that caused by the introduction of a needle in accordance with good veterinary practice". Objective criteria will need to identified by which it is possible to determine whether a particular procedure causes pain, suffering, distress or lasting harm equivalent or higher than that caused by the skilled introduction of a needle. In addition, the Directive also makes specific references to humane methods of killing (Article 6) and the use of anaesthesia and analgesia (Article 14). The potential impact upon many aspects of cephalopod research in general and the broad range of neuroscience research in particular is considerable. To illustrate this, examples of published studies are listed in Table 4, which are now likely to be regulated under the scope of the Directive if performed in the EU. In this section, we focus on some specific aspects to illustrate some challenges to neuroscience research presented by the above aspects of the Directive.
Pain, suffering, distress and lasting harm (PSDLH)

One of several drivers for the inclusion of cephalopods in the Directive was a review of the evidence relating to their ability to perceive pain (EFSA Panel on Animal Health and Welfare 2005). The criteria used in the EFSA report have recently been reviewed in detail (Andrews et al. 2013) as has nociception in invertebrates (Crook and Walters 2011). At the time of the EFSA report (2005), evidence for the existence of nociceptors in cephalopods was largely circumstantial. Recently, afferents with the characteristics of nociceptors sensitive to mechanical stimulation have been described in a squid and evidence provided for long-term sensitisation (Crook et al. 2013). However, there are major gaps in our knowledge of the central processing of the information arising from the nociceptors in invertebrates in general and cephalopods specifically (Crook and Walters 2011; Andrews et al. 2013). The anatomy of the afferent projections from the arms and various lobes of the brain has been described for O. vulgaris, S. officinalis and L. vulgaris (Budelmann and Young 1985, 1987), but again neurophysiological studies are needed to understand the central processing of information from well-characterised nociceptors. Until such studies are performed, "pain perception" (i.e. what the animal might "feel" as a result of nociceptor activation) in cephalopods will remain a contentious issue. However, from an animal welfare perspective, researchers should be mindful of stimuli likely to activate nociceptors in their experimental protocols and either justify their use or take action to mitigate the impact. Neurophysiological studies in combination with behavioural studies will also be required to identify substances with analgesic effects that can be used postoperatively and to identify the mechanism(s) by which substances with presumed general anaesthetic actions in cephalopods act.

In addition to the physiology and pharmacology of pain perception in cephalopods, objective criteria for the identification and measurement of pain are required as part of welfare assessment and in particular to assess the impact of any experimental intervention. Although a great emphasis is rightly placed upon pain, equal consideration needs to be given to other ways in which an animal may suffer, be in distress or be caused lasting harm in an experimental setting and ways in which they can be identified and measured. Examples of "non-painful" types of suffering could include isolation in social species, housing in a tank of inappropriate size or with no refuge or being caused fear and anxiety (see Hawkins et al. 2011b for other examples). A preliminary approach to monitoring PSDLH in cephalopods has been recently described (see Table 1 in Andrews et al. 2013) based upon the types of criteria that have been developed over 
Table 4 Examples of published research on cephalopods which if carried out in the EU would now be likely to come within the scope of Directive 2010/63/EU

Research topic or technique
Implantation of electromyographic electrodes under anaesthesia in cuttlefish
fin muscle and recording from unanaesthetised animals
Removal of optic glands under anaesthesia followed by recovery (study
effect on senescence)
Sampling of haemolymph usually under anaesthesia
Implantation of a catheter into the dorsal aorta for administration of drugs to
the brain
Investigation of the efficacy of different anaesthetic techniques and
mechanisms of anaesthesia

Implantation of electrodes for recording or stimulation into the brain under anaesthesia followed by investigation of the effects in the conscious animal

Removal of an arm or a tentacle with or without anaesthesia to investigate regeneration or the acute tissue and behavioural response to injury

Administration of substances into the circulation via the branchial hearts or intramuscular routes or directly into the brain

Tracing nerve pathways using marker injection under anaesthesia followed by recovery to allow marker transport

Implantation of electronic tags for tracking movement in the wild

Noninvasive measurement of brain size and arm morphology under anaesthesia with or without recovery

Killing animals (including hatchlings) to remove tissue (e.g. arm, brain), for study in vitro (e.g. brain slices), histological and molecular studies particularly if the study involves "nonstandard" methods

Brain or peripheral nervous system lesions under anaesthesia followed by recovery

Use of aversive stimuli (e.g. electric shock, bitter taste) in training protocols

Deprivation of food for 5 days, feeding with barium sulphate labelled shrimps, constraint of the animal and exposure to X-rays for imaging gut contents

Exposure of an animal to a potentially "stressful" environment/stimulus as an experimental procedure; examples include a large moving shape, a larger conspecific, a predator, air or sea water with temperature or oxygen partial pressure outside the normal aquarium range or manipulation of natural photoperiod/light intensity. Noninvasive immobilisation (confinement) may also constitute a stressful stimulus. The intensity, duration and exposure frequency are all factors which need to be considered

Production of hatchlings with deleterious phenotypes/genotypes by exposure of the eggs to a harmful environment or mutagen or genetic manipulation
References

Kier et al. (1989)

Wodinsky (1977)

Malham et al. (1998a), Collins and Nyholm (2010), Grimaldi et al. (2013), Locatello et al. (2013)

Andrews et al. (1981)

Andrews and Tansey (1981), Messenger et al. (1985), Seol et al. (2007), Sen and Tanrikul (2009), Pagano et al. (2011), Goncalves et al. (2012), Gleadall (2013)

Chichery and Chanelet (1976), Brown et al. (2006), Shomrat et al. (2008), Zullo et al. (2009), Mooney et al. (2010), Shomrat et al. (2011)

Lange (1920), Crook et al. (2011), Fossati et al. (2013), Tressler et al. (2013)

Agnisola et al. (1996), Fiorito et al. (1998), Agin et al. (2003), Graindorge et al. (2008)

Gaston and Tublitz (2004), Tublitz et al. (2006)

Wearmouth et al. (2013)

Grimaldi et al. (2007), Margheri et al. (2011b)

Kier et al. (1989), Westermann et al. (2002), Hochner et al. (2003), Kier and Stella (2007), Mackie (2008), Hague et al. (2013)

Fiorito and Chichery (1995), Sumbre et al. (2001), Graindorge et al. (2006, 2008)

Robertson et al. (1994, 1995, 1996), Darmaillacq et al. (2004), Borrelli (2007)

Westermann et al. (2002)

Malham et al. (2002), Cole and Adamo (2005), King and Adamo (2006), Adamo et al. (2006), Kuba et al. (2006), Canali et al. (2011a)

Rosa et al. (2012)

Note that not all examples relate to invasive or surgical procedures (see also Ponte et al. 2013 for other resources). Papers have been selected to illustrate the diversity of studies likely to be regulated, and no comment is made about whether a particular study would now be permitted by a particular national competent authority

many years for mammals (e.g. Morton and Griffiths 1985). ${ }^{7}$

\footnotetext{
7 For severity assessment see also: http://ec.europa.eu/environment/ chemicals/lab_animals/pdf/Consensus\%20doc\%20on\%20severity\% 20assessment.pdf.
}

\section{General anaesthesia}

General anaesthesia is required for performing surgical procedures followed by recovery (e.g. selective brain or nerve lesions, implantation of telemetry devices) for some types of in vivo physiological study (e.g. reflex control of 
the cardio-respiratory system, investigation of somatosensory processing) and to permit handling for veterinary investigation and treatment. Over the last century, a diverse range of substances has been used to induce general anaesthesia in cephalopods (Pagano et al. 2011; Goncalves et al. 2012; Gleadall 2013; Andrews et al. 2013), but there have been relatively few studies utilising objective criteria to define the anaesthetic state or the mechanism and site of action and little consideration has been given to the procedures used from a welfare perspective (e.g. how aversive are the agents used?). Recently, isoflurane as been tested as an anaesthetic in $O$. vulgaris (Di Cosmo, pers. communication), but more investigation is required.

All current techniques use immersion in sea water containing the anaesthetic agent. Magnesium chloride and ethanol, used either separately or in combination, are the most commonly used agents. Following Andrews et al. (2013), criteria for assessment of general anaesthesia in cephalopods include: (1) depression of ventilation and in some cases cessation, probably accompanied by reduced cardiac activity; (2) decrease in chromatophore tone (indicative of reduced drive to or from the sub-oesophageal chromatophore lobes); (3) reduced arm activity, tone and sucker adhesion (particularly octopus); (4) loss of normal posture and righting reflex; (5) reduced or absent response to a noxious stimulus. The last needs to be used with some care as in $O$. vulgaris arms removed from the body withdraw in response to a noxious stimulus (Hague et al. 2013). Studies are urgently required to understand the way in which the putative anaesthetic agents act on the nervous system to produce the above effects and to render the animal into a presumed state of insensibility and unconsciousness. The site and mechanism of action of general anaesthetics has been studied extensively in mammals (e.g. Angel 1993), but there are few studies in cephalopods (e.g.: Andrews and Tansey 1981; Messenger et al. 1985), although with their high degree of encephalization combined with a brain organised in a fundamentally different way from vertebrates studies of general anaesthesia may provide novel insights into mechanisms of consciousness.

\section{Humane methods of killing}

The Directive requires that if it is necessary to kill an animal (e.g. at the end of project, to obtain tissue for an in vitro study, because a humane end point is reached), it must be done "with the minimum of pain, suffering and distress" (Article 6). Acceptable methods should comply with the general principles of humane animal euthanasia set out in Demers et al. (2006) and Annex IV of the Directive.

Identification of humane methods for killing is a particular challenge for neuroscience as physical destruction of the brain is a commonly used method and maybe acceptable if the method used can be demonstrated to be humane, but it is obviously not suitable when the brain is the subject of study. Similarly, overdose of general anaesthetic is often used, but again could be argued to compromise subsequent studies of brain function because of the residual pharmacological effect of the agent used and the effects of asphyxia caused by the prolonged (usually $>30 \mathrm{~min}$ ) immersion in anaesthetic needed to kill the animal. Such constraints may encourage investigation of electrical euthanasia methods similar to those used for crustaceans (Neill 2010). Annex IV of the Directive also includes methods for confirmation of death, and these are discussed in relation to cephalopods in Andrews et al. (2013). It should also be noted that the requirement for humane killing also applies to hatchlings. In this last case, killing by direct immersion in fixative would not now be considered acceptable in the EU, although it might be possible to obtain permission to use this as a method if it could be justified to the NCA.

Humane killing methods for both hatchlings and developmental stages through adult cephalopods require additional research, but in the interim it is proposed that animals are either anaesthetised prior to mechanical destruction of the brain (this may be difficult in nautiloids) or if the brain is required that animals (including hatchlings) are killed by prolonged immersion in anaesthetic, recognising that the impact upon the brain will need to be considered in the light of the scientific objectives and that a shorter period of anaesthesia followed by decapitation when the animal is insensible may need to be considered (Andrews et al. 2013).

\section{Replacement, refinement and reduction and cephalopod research}

The principles of Replacement, Refinement and Reduction ("3Rs") developed by Russell and Burch (1959) as key elements of humane experimentation involving sentient animals are at the heart of the Directive (Article 4), and project evaluation prior to authorisation requires an assessment of how the 3 Rs are addressed in the proposed study (Article 38). Replacement "of the use of a regulated living animal" is often used in the context of pharmaceutical research to describe replacing a test (e.g. for drug efficacy) in a living animal with one using a microorganism, human tissue or in silico methods. Superficially, "replacement" may not appear to apply to most cephalopod research as many researchers are undertaking the research because they have a specific interest in an aspect to cephalopod biology, but "replacement" requires researchers to consider a priori whether they need to use a "living animal" (of a species covered by the Directive) to 
answer the specific research question or whether the same research question could be tackled in another way which could e.g. include in vitro studies of tissue take from the same species provided that the animal is killed using an approved humane method.

Most researchers will already be applying the principle of "reduction" to their studies as this relates to the use of the minimum number of animals required to achieve the scientific objectives of the project and is an inherent part of good experimental and statistical design. Although not strictly an example of "reduction" within the meaning of the 3Rs the Directive also makes a specific point (Article 18) about sharing organs and tissues from killed animals. This could contribute to a reduction in the overall number of animals used within an institute by coordinating the killing animals at the end of a procedure with in vitro studies requiring fresh living tissue and/or banking tissue for molecular or histological studies. In the case of the latter, tissue could be shipped to other institutions.

Refinement is the " $R$ " most likely to impinge upon current cephalopod research by requiring that experimental procedures, housing, husbandry and all aspects of care are "refined" so that they cause the minimum possible pain, suffering, distress or lasting harm throughout the life of the animal being used. Refinement of current best practice in the care and welfare assessment of the various cephalopod species will evolve by research to provide evidence to support changes of approach and technique that reduce adverse effects and maybe informed by approaches to refining procedures commonly carried out on laboratory vertebrates (Hawkins et al. 2011a). For experimental procedures, refinement requires the researcher to carefully examine their protocols and see where changes in can be made in any aspect likely to cause PSDLH to reduce adverse effects whilst achieving the scientific outcome. For example, it might be asked whether the number of haemolymph samples taken or number of drug doses given each day could be reduced; or whether positive reinforcement could be used instead of negative ones in training protocols; and whether induction of general anaesthesia could be made more humane by exposing the animal to a gradually rising concentration of anaesthetic rather than direct immersion in a fully effective concentration. All three are examples of approaches accepted and used to refine procedures in vertebrates. Additional examples using hypothetical research projects involving cephalopods are discussed in Smith et al. (2013).

\section{Conclusion}

Directive 2010/63/EU is a milestone for invertebrate research in the EU because it is the first time particular types of research involving an entire class of invertebrates, the cephalopods, will be regulated in the same way as scientific projects involving vertebrates. Although regulation presents challenges, there are several areas where neurophysiological and behavioural neuroscience research could be useful to address key questions related to cephalopod care and welfare discussed above. Most researchers already recognise the relationship between good welfare and good science, but the development of consensus Guidelines for Care and Welfare of Cephalopods led by the research community will facilitate the dissemination and adoption of good practice. Guidelines are being developed based upon literature review and discussion meetings, but they are only an initial step and evolution of such guidelines will rely upon capturing the experience and knowledge of the cephalopod research community. It is hoped that this review will prompt readers to investigate some of the neuroscience questions posed and to contribute to the future development of guidelines for optimal care and welfare of cephalopods via publication and contributions to online research fora (e.g. CephRes: www.cephalopodresearch.org; CephSeq: http://cephseq.org/; Cephalopod International Advisory Council: http://www.abdn.ac.uk/CIAC/).

Acknowledgments Most of the authors of this paper participate to the recently established COST network, Action FA 1301-CephsInAction (http://www.cost.eu/domains_actions/fa/Actions/FA1301). N.S., M.K., F.G., F.M. collated the contributions from the April 2012 Meeting in Vico Equense that provide the ground for this work. P.A., M.K., N.S. and G.F. drafted and edited the final manuscript with comments from several authors. P.A. and G.F. conceived this work. G.F. and G.P. organised the meeting and provided assistance to the group on behalf of CephRes. D.M. has been supported by POR Campania FSE 2007-2013, Project MODO - Model Organism. In addition, CephRes thanks the Municipality of Vico Equense, Mrs Rosaria Savarese for their hospitality and friendly assistance. Concetta Maffucci and Piero Amodio assisted the CephRes team and the Authors of this paper and facilitated group meetings and discussions.

\section{Conflict of interest None.}

Open Access This article is distributed under the terms of the Creative Commons Attribution License which permits any use, distribution, and reproduction in any medium, provided the original author(s) and the source are credited.

\section{References}

Abbott NJ, Williamson R, Maddock L (1995) Cephalopod neurobiology: neuroscience studies in squid, octopus and cuttlefish. Oxford University Press, Oxford

Adamo SA, Ehgoetz K, Sangster C, Whitehorne I (2006) Signaling to the enemy? Body pattern expression and its response to external cues during hunting in the cuttlefish Sepia officinalis (Cephalopoda). Biol Bull 210:192-200

Advocates for Animals (2005) Cephalopods and decapod crustaceans. Their capacity to experience pain and suffering. Advocates for Animals, Edinburgh

Agin V, Chichery R, Chichery MP (2001) Effects of learning on cytochrome oxidase activity in cuttlefish brain. NeuroReport $12: 113-116$ 
Agin V, Chichery R, Maubert E, Chichery MP (2003) Timedependent effects of cycloheximide on long-term memory in the cuttlefish. Pharmacol Biochem Behav 75:141-146

Agin W, Chichery R, Dickel L, Chichery MP (2006) The "prawn-inthe-tube" procedure in the cuttlefish: habituation or passive avoidance learning? Learn Mem 13:97-101

Agnisola C, Castaldo P, Fiorito G (1996) Octopus vulgaris (Mollusca, Cephalopoda) as a model in behavioral pharmacology: a test of handling effects. Physiol Behav 59:729-733

Albertin CB, Bonnaud L, Brown CT, Crookes-Goodson WJ, da Fonseca RR, Di Cristo C, Dilkes BP, Edsinger-Gonzales E, Freeman RM Jr, Hanlon RT, Koenig KM, Lindgren AR, Martindale MQ, Minx P, Moroz LL, Nodl MT, Nyholm SV, Ogura A, Pungor JR, Rosenthal JJ, Schwarz EM, Shigeno S, Strugnell JM, Wollesen T, Zhang G, Ragsdale CW (2012) Cephalopod genomics: a plan of strategies and organization. Stand Genomic Sci 7:175-188

Allen JJ, Mäthger LM, Buresch KC, Fetchko T, Gardner M, Hanlon RT (2010) Night vision by cuttlefish enables changeable camouflage. J Exp Biol 213:3953-3960

Anderson RC, Wood JB (2001) Enrichment for giant Pacific octopuses: happy as a clam? J Appl Anim Welf Sci 4:157-168

Anderson RC, Wood JB, Byrne RA (2002) Octopus senescence: the beginning of the end. J Appl Anim Welf Sci 5:275-283

André M, Solé M, Lenoir M, Durfort M, Quero C, Mas A, Lombarte A, van der Schaar M, López-Bejar M, Morell M, Zaugg S, Houégnigan L (2011) Low-frequency sounds induce acoustic trauma in cephalopods. Front Ecol Environ 9:489-493

Andrews PLR (2011a) Laboratory invertebrates: only spineless, or spineless and painless? Introduction. ILAR J 52:121-125

Andrews PLR (2011b) Practical implications for cephalopod researchers in the implementation of Directive 2010/63/EU. J Shellfish Res 30:995

Andrews PLR, Tansey EM (1981) The effects of some anesthetic agents in Octopus vulgaris. Comp Biochem Physiol 70C:241-247

Andrews PLR, Messenger JB, Tansey EM (1981) Color changes in cephalopods after neurotransmitter injection into the cephalic aorta. Proc R Soc Lond B 213:93-99

Andrews PLR, Darmaillacq AS, Dennison N, Gleadall IG, Hawkins P, Messenger JB, Osorio D, Smith VJ, Smith JA (2013) The identification and management of pain, suffering and distress in cephalopods, including anesthesia, analgesia and humane killing. J Exp Mar Biol Ecol. doi:10.1016/j.jembe.2013.02.010

Angel A (1993) Central neuronal pathways and the process of anesthesia. Br J Anaesth 71:148-163

Animal Behaviour (2012) Guidelines for the treatment of animals in behavioural research and teaching. Anim Behav 83:301-309

Arkhipkin AI (2005) Statoliths as 'black boxes' (life recorders) in squid. Mar Freshw Res 56:573-583

Arkhipkin AI, Shcherbich ZN (2012) Thirty years' progress in age determination of squid using statoliths. J Mar Biol Assoc UK 92:1389-1398

Baratte S, Bonnaud L (2009) Evidence of early nervous differentiation and early catecholaminergic sensory system during Sepia officinalis embryogenesis. J Comp Neurol 517:539-549

Barbato M, Bernard M, Borrelli L, Fiorito G (2007) Body patterns in cephalopods "polyphenism" as a way of information exchange. Pattern Recognit Lett 28:1854-1864

Bardou I, Maubert E, Leprince J, Chichery R, Cocquerelle C, Launay S, Vivien D, Vaudry H, Agin V (2009) Distribution of oxytocinlike and vasopressin-like immunoreactivities within the central nervous system of the cuttlefish, Sepia officinalis. Cell Tissue Res 336:249-266

Bardou I, Leprince J, Chichery R, Vaudry H, Agin V (2010) Vasopressin/oxytocin-related peptides influence long-term memory of a passive avoidance task in the cuttlefish, Sepia officinalis. Neurobiol Learn Mem 93:240-247

Barry PD, Tamone SL, Tallmon DA (2011) A comparison of tagging methodology for North Pacific giant octopus Enteroctopus dofleini. Fish Res 109:370-372

Bateson P (1991) Assessment of pain in animals. Anim Behav 42:827-839

Bettencourt V, Guerra A (2000) Growth increments and biomineralization process in cephalopod statoliths. J Exp Mar Biol Ecol 248:191-205

Bettencourt V, Coelho L, Andrade JP, Guerra A (1996) Age and growth of the squid Loligo vulgaris off the south coast of Portugal, using statolith analysis. J Mollusc Stud 62:359-366

Bloedel J, Gage PW, Llinas RR, Quastel DM (1966) Transmitter release at the squid giant synapse in the presence of tetrodotoxin. Nature 212:49-50

Boal JG (1996) A review of simultaneous visual discrimination as a method of training octopuses. Biol Rev 71:157-189

Boal JG (2006) Social recognition: a top down view of cephalopod behaviour. Vie Milieu 56:69-79

Boal JG (2011) Behavioral research methods for octopuses and cuttlefishes. Vie et Milieu Life Environ 61:203-210

Boal JG, Golden DK (1999) Distance chemoreception in the common cuttlefish, Sepia officinalis (Mollusca, Cephalopoda). J Exp Mar Biol Ecol 235:307-317

Boal JG, Gonzalez SA (1998) Social behaviour of individual oval squids (Cephalopoda, Teuthoidea, Loliginidae, Sepioteuthis lessoniana) within a captive school. Ethology 104:161-178

Boal JG, Wittenberg KM, Hanlon RT (2000) Observational learning does not explain improvement in predation tactics by cuttlefish (Mollusca: Cephalopoda). Behav Proc 52:141-153

Boletzky SV, Hanlon RT (1983) A review of the laboratory maintenance, rearing and culture of cephalopod molluscs. Mem Natl Mus Vic 44:147-187

Borrelli L (2007) Testing the contribution of relative brain size and learning capabilities on the evolution of Octopus vulgaris and other cephalopods. PhD thesis, Stazione Zoologica Anton Dohrn, Napoli, Italy. Open University, London

Borrelli L, Fiorito G (2008) Behavioral analysis of learning and memory in cephalopods. In: Byrne JJ (ed) Learning and memory: a comprehensive reference. Academic Press, Oxford, pp 605-627

Borrelli L, Gherardi F, Fiorito G (2006) A catalogue of body patterning in cephalopoda. Stazione Zoologica A. Dohrn, Napoli

Boycott BB (1954) Learning in Octopus vulgaris and other cephalopods. Pubbl Staz Zool Napoli 25:67-93

Boyer C, Maubert E, Charnay Y, Chichery R (2007) Distribution of neurokinin A-like and serotonin immunoreactivities within the vertical lobe complex in Sepia officinalis. Brain Res 1133:53-66

Boyle PR (1981) Methods for the aquarium maintenance of the common octopus of British Waters, Eledone cirrhosa. Lab Anim $15: 327-331$

Boyle PR (1991) The UFAW handbook on the care and management of cephalopods in the laboratory. Universities Federation for Animal Welfare, Potters Bar

Boyle P, Rodhouse P (2005) Cephalopods: ecology and fisheries. Blackwell Science, Ames

Braid HE, Deeds J, DeGrasse SL, Wilson JJ, Osborne J, Hanner RH (2012) Preying on commercial fisheries and accumulating paralytic shellfish toxins: a dietary analysis of invasive Dosidicus gigas (Cephalopoda Ommastrephidae) stranded in Pacific Canada. Mar Biol 159:25-31

Brewer RS, Norcross BL (2012) Long-term retention of internal elastomer tags in a wild population of North Pacific giant octopus (Enteroctopus dofleini). Fish Res 134-136:17-20

Broom DM (1991a) Animal-welfare-concepts and measurement. J Anim Sci 69:4167-4175 
Broom DM (1991b) Assessing welfare and suffering. Behav Proc 25:117-123

Broom DM (2011) A history of animal welfare science. Acta Biotheor 59:121-137

Brown ER, Piscopo S (2013). Synaptic plasticity in cephalopods; more than just learning and memory? Invert Neurosci 13. doi:10. 1007/s10158-013-0150-4

Brown ER, Piscopo S, De Stefano R, Giuditta A (2006) Brain and behavioural evidence for rest-activity cycles in Octopus vulgaris. Behav Brain Res 172:355-359

Budelmann BU (1995) The cephalopod nervous system: what evolution has made of the molluscan design. In: Breidbach $\mathrm{O}$, Kutsch W (eds) The nervous systems of invertebrates: an evolutionary and comparative approach. Birkhäuser Verlag, Basel, pp 115-138

Budelmann BU (1998) Autophagy in octopus. S Afr J Mar Sci 20:101-108

Budelmann BU, Bonn U (1982) Histochemical evidence for catecholamines as neurotransmitters in the statocyst of Octopus vulgaris. Cell Tissue Res 227:475-483

Budelmann BU, Young JZ (1985) Central pathways of the nerves of the arms and mantle of Octopus. Philos Trans R Soc Lond B 310:109-122

Budelmann BU, Young JZ (1987) Brain pathways of the brachial nerves of Sepia and Loligo. Philos Trans R Soc Lond Ser B Biol Sci 315:345-352

Budelmann BU, Schipp R, Boletzky SV (1997) Cephalopoda. In: Harrison FW, Kohn AJ (eds) Microscopic anatomy of invertebrates. Wiley-Liss, New York, pp 119-414

Bullock TH (1948) Properties of a single synapse in the stellate ganglion of squid. J Neurophysiol 11:343-364

Bullock TH (1965) Mollusca: Cephalopoda. In: Bullock TH, Horridge GA (eds) Structure and function in the nervous systems of invertebrates. W.H. Freeman and Company, San Francisco, pp 1433-1515

Bullock AM, Polglase JL, Phillips SE (1987) The wound healing and haemocyte response in the skin of the lesser octopus Eledone cirrhosa (Mollusca: Cephalopoda) in the presence of Vibrio tubiashii. J Zool 211:373-385

Bustamante P, Gonzalez AF, Rocha F, Miramand P, Guerra A (2008) Metal and metalloid concentrations in the giant squid Architeuthis dux from Iberian waters. Mar Environ Res 66:278-287

Byrne RA, Kuba MJ, Meisel DV, Griebel U, Mather JA (2006a) Does Octopus vulgaris have preferred arms? J Comp Psychol 120:198-204

Byrne RA, Kuba MJ, Meisel DV, Griebel U, Mather JA (2006b) Octopus arm choice is strongly influenced by eye use. Behav Brain Res 172:195-201

Calisti M, Giorelli M, Levy G, Mazzolai B, Hochner B, Laschi C, Dario P (2011) An octopus-bioinspired solution to movement and manipulation for soft robots. Bioinspir Biomim 6:036002

Callaerts P, Lee PN, Hartmann B, Farfan C, Choy DW, Ikeo K, Fischbach KF, Gehring WJ, de Couet HG (2002) HOX genes in the sepiolid squid Euprymna scolopes: implications for the evolution of complex body plans. Proc Natl Acad Sci USA 99:2088-2093

Canali E, Ponte G, Belcari P, Rocha F, Fiorito G (2011a) Evaluating age in Octopus vulgaris: estimation, validation and seasonal differences. Mar Ecol Progr Ser 441:141-149

Canali E, Ponte G, Belcari P, Rocha F, Fiorito G (2011b) Evaluating age in the cephalopod mollusc Octopus vulgaris: analysis of growth increments in the upper beaks. J Shellfish Res 30:996-997

Castellanos-Martinez S, Gestal C (2011) Immune response of Octopus vulgaris against the infection by the gastrointestinal parasite Aggregata octopiana. J Shellfish Res 30:997-998
Castellanos-Martinez S, Gestal C (2013) Pathogens and immune response of cephalopods. J Exp Mar Biol Ecol. doi:10.1016/ jembe.2013.02.007

Chichery R, Chanelet J (1976) Motor and behavioral-responses obtained by stimulation with chronic electrodes of optic lobe of Sepia officinalis. Brain Res 105:525-532

Chichery MP, Chichery R (1992a) Behavioral and neurohistological changes in aging Sepia. Brain Res 574:77-84

Chichery R, Chichery MP (1992b) Learning performances and aging in cuttlefish (Sepia officinalis). Exp Gerontol 27:233-239

Choe SANG (1963) Daily age markings on the shell of cuttlefishes. Nature 197:306-307

Cirillo T, Fasano E, Viscardi V, Arnese A, Amodio-Cocchieri R (2010) Survey of lead, cadmium, mercury and arsenic in seafood purchased in Campania, Italy. Food Addit Contam Part B Surveill 3:30-38

Cole PD, Adamo SA (2005) Cuttlefish (Sepia officinalis: Cephalopoda) hunting behavior and associative learning. Anim Cogn 8:27-30

Coles JA, Abbott NJ (1996) Signalling from neurones to glial cells in invertebrates. Trends Neurosci 19:358-362

Collins AJ, Nyholm SV (2010) Obtaining hemocytes from the Hawaiian bobtail squid Euprymna scolopes and observing their adherence to symbiotic and non-symbiotic bacteria. J Vis Exp e1714

Collins AJ, LaBarre BA, Won BSW, Shah MV, Heng S, Choudhury MH, Haydar SA, Santiago J, Nyholm SV (2012) Diversity and partitioning of bacterial populations within the accessory nidamental gland of the squid Euprymna scolopes. Appl Environ Microbiol 78:4200-4208

Conti L, Limon A, Palma E, Miledi R (2013) Microtransplantation of cellular membranes from squid stellate ganglion reveals ionotropic GABA receptors. Biol Bull 224:47-52

Cornwell CJ, Messenger JB, Williamson R (1993) Distribution of GABA-like immunoreactivity in the octopus brain. Brain Res 621:353-357

Costa PR, Pereira J (2010) Ontogenic differences in the concentration of domoic acid in the digestive gland of male and female Octopus vulgaris. Aquat Biol 9:221-225

Costa PR, Rosab R, Duarte-Silva A, Brotas V, Sampayo MAM (2005) Accumulation, transformation and tissue distribution of domoic acid, the amnesic shellfish poisoning toxin, in the common cuttlefish, Sepia officinalis. Aquat Toxicol 74:82-91

Crook RJ, Walters ET (2011) Nociceptive behavior and physiology of molluscs: animal welfare implications. ILAR J 52:185-195

Crook RJ, Lewis T, Hanlon RT, Walters ET (2011) Peripheral injury induces long-term sensitization of defensive responses to visual and tactile stimuli in the squid Loligo pealeii, Lesueur 1821. J Exp Biol 214:3173-3185

Crook RJ, Hanlon RT, Walters ET (2013) Squid have nociceptors that display widespread long-term sensitization and spontaneous activity after bodily injury. J Neurosci 33:10021-10026

Darmaillacq AS, Dickel L, Chichery MP, Agin V, Chichery R (2004) Rapid taste aversion learning in adult cuttlefish, Sepia officinalis. Anim Behav 68:1291-1298

Darmaillacq AS, Chichery R, Dickel L (2006) Food imprinting, new evidence from the cuttlefish Sepia officinalis. Biol Lett 2:345-347

Davis H, Balfour D (1992) The inevitable bond: examining scientistanimal interactions. Cambridge University Press, Cambridge

de Polo A, Scrimshaw MD (2012) Challenges for the development of a biotic ligand model predicting copper toxicity in estuaries and seas. Environ Toxicol Chem 31:230-238

Demers G, Griffin G, De Vroey G, Haywood JR, Zurlo J, Bedard M (2006) Harmonization of animal care and use guidance. Science 312:700-701 
DeTolla LJ, Srinivas S, Whitaker BR, Andrews C, Hecker B, Kane AS, Reimschuessel R (1995) Guidelines for the care and use of fish in research. ILAR J 37:159-173

Di Cosmo A, Paolucci M, Di Cristo C (2004) $N$-methyl-D-aspartate receptor-like immunoreactivity in the brain of Sepia and Octopus. J Comp Neurol 477:202-219

Di Cosmo A, Di Cristo C, Messenger JB (2006) L-Glutamate and its ionotropic receptors in the nervous system of cephalopods. Curr Neuropharmacol 4:305-312

Di Cosmo A, Di Cristo C, Palumbo A, d'Ischia M, Messenger JB (2007) Nitric oxide synthase (NOS) in the brain of the cephalopod Sepia officinalis. J Comp Neurol 428:411-427

Di Cristo C, Fiore G, Scheinker V, Enikolopov G, d'Ischia M, Palumbo A, Di Cosmo A (2007) Nitric oxide synthase expression in the central nervous system of Sepia officinalis: an in situ hybridization study. Eur J Neurosci 26:1599-1610

Dickel L, Boal JG, Budelmann BU (2000) The effect of early experience on learning and memory in cuttlefish. Dev Psychobiol 36:101-110

Domingues P, Sykes A, Sommerfield A, Almansa E, Lorenzo A, Andrade JP (2004) Growth and survival of cuttlefish (Sepia officinalis) of different ages fed crustaceans and fish. Effects of frozen and live prey. Aquaculture 229:239-254

Dumont E, Chichery MP, Nouvelot A, Chichery R (1994) Variations of the lipid constituents in the central-nervous-system of the cuttlefish (Sepia officinalis) during aging. Comp Biochem Physiol A Physiol 108:315-323

Edelman DB (2011) How octopuses see the world and other roads less travelled: necessity versus sufficiency and evolutionary convergence in the study of animal consciousness. J Shellfish Res 30:1001

Edelman DB, Seth AK (2009) Animal consciousness: a synthetic approach. Trends Neurosci 32:476-484

EFSA Panel on Animal Health and Welfare (2005) Opinion of the Scientific Panel on Animal Health and Welfare (AHAW) on a request from the Commission related to the "aspects of the biology and welfare of animals used for experimental and other scientific purposes". EFSA J 292:1-136

Ellis R (1998) The giant squid in literature and cinema. In: Ellis R (ed) The search for the giant squid: the biology and mythology of the world's most elusive sea creature. The Lyons Press, New York, pp 167-212

Estefanell J, Socorro J, Afonso JM, Roo J, Fernandez-Palacios H, Izquierdo MS (2011) Evaluation of two anaesthetic agents and the passive integrated transponder tagging system in Octopus vulgaris (Cuvier 1797). Aquac Res 42:399-406

European Parliament, Council of the European Union (2010) Directive 2010/63/EU of the European Parliament and of the Council of 22 September 2010 on the protection of animals used for scientific purposes. Council of Europe, Strasbourg

Féral J-P (1988) Wound healing after arm amputation in Sepia officinalis (Cephalopoda: Sepioidea). J Invertebr Pathol 52:380-388

Ferreira A, Marquez L, Almansa E, Andrade JP, Lorenzo A, Domingues PM (2010) The use of alternative diets to culture juvenile cuttlefish, Sepia officinalis: effects on growth and lipid composition. Aquac Nutr 16:262-275

Fewtrell JL, McCauley RD (2012) Impact of air gun noise on the behaviour of marine fish and squid. Mar Pollut Bull 64:984-993

Fiore G, Poli A, Di Cosmo A, d'Ischia M, Palumbo A (2004) Dopamine in the ink defence system of Sepia officinalis: biosynthesis, vesicular compartmentation in mature ink gland cells, nitric oxide (NO)/cGMP-induced depletion and fate in secreted ink. Biochem J 378:785-791

Fiorito G (1986) Is there pain in invertebrates? Behav Proc 12:383-388

Fiorito G, Chichery R (1995) Lesions of the vertical lobe impair visual discrimination learning by observation in Octopus vulgaris. Neurosci Lett 192:117-120
Fiorito G, Scotto P (1992) Observational learning in Octopus vulgaris. Science 256:545-547

Fiorito G, von Planta C, Scotto P (1990) Problem solving ability of Octopus vulgaris Lamarck (Mollusca, Cephalopoda). Behav Neural Biol 53:217-230

Fiorito G, Agnisola C, d'Addio M, Valanzano A, Calamandrei G (1998) Scopolamine impairs memory recall in Octopus vulgaris. Neurosci Lett 253:87-90

Florey E (1963) Acetylcholine in invertebrate nervous systems. Can J Biochem Physiol 41:2619-2626

Florey E, Winesdorfer J (1968) Cholinergic nerve endings in Octopus vulgaris. J Neurochem 15:169-177

Florini M, Fiorito G, Hague T, Andrews PLR (2011) "Monco": a natural model for studying arm usage and regeneration in Octopus vulgaris. J Shellfish Res 30:1002

Ford LA (1992) Host defense mechanisms of cephalopods. Annu Rev Fish Dis 2:25-41

Fossati SM, Carella F, De Vico G, Benfenati F, Zullo L (2013) Octopus arm regeneration: role of acetylcholinesterase during morphological modification. J Exp Mar Biol Ecol. doi:10.1016/j. jembe.2013.02.015

Frank MG, Waldrop RH, Dumoulin M, Aton S, Boal JG (2012) A preliminary analysis of sleep-like states in the cuttlefish Sepia officinalis. PLoS One 7(6):e38125

Galitsopoulou A, Georgantelis D, Kontominas MG (2009) Cadmium content in fresh and canned squid (Loligo opalescens) from the Pacific coastal waters of California (USA). Food Addit Contam Part B Surveill 2:38-43

Gaston MR, Tublitz NJ (2004) Peripheral innervation patterns and central distribution of fin chromatophore motoneurons in the cuttlefish Sepia officinalis. J Exp Biol 207:3089-3098

Gestal C, Nigmatullin CM, Hochberg FG, Guerra A, Pascual S (2005) Aggregata andresi n. sp (Apicomplexa: Aggregatidae) from the ommastrephid squid Martialia hyadesi in the SW Atlantic Ocean and some general remarks on Aggregata spp. in cephalopod hosts. Syst Parasitol 60:65-73

Gherardi F (2009) Behavioural indicators of pain in crustacean decapods. Ann Ist Super Sanità 45:432-438

Gleadall IG (2013) The effects of prospective anaesthetic substances on cephalopods: summary of original data and a brief review of studies over the last two decades. J Exp Mar Biol Ecol. doi:10. 1016/j.jembe.2013.02.008

Goncalves RA, Aragao C, Frias PA, Sykes AV (2012) The use of different anaesthetics as welfare promoters during short-term human manipulation of European cuttlefish (Sepia officinalis) juveniles. Aquaculture 370:130-135

Graindorge N, Alves C, Darmaillacq AS, Chichery R, Dickel L, Bellanger C (2006) Effects of dorsal and ventral vertical lobe electrolytic lesions on spatial learning and locomotor activity in Sepia officinalis. Behav Neurosci 120:1151-1158

Graindorge N, Jozet-Alves C, Chichery R, Dickel L, Bellanger C (2008) Does kainic acid induce partial brain lesion in an invertebrate model: Sepia officinalis? Comparison with electrolytic lesion. Brain Res 1238:44-52

Grasso FW (2008) Octopus sucker-arm coordination in grasping and manipulation. Am Malacol Bull 24:13-23

Grasso F, Setlur P (2007). Inspiration, simulation and design for smart robot manipulators from the sucker actuation mechanism of cephalopods. Bioinspir Biomim 2. doi:10.1088/1748-3182/2/4/S06

Grimaldi A, Tettamanti G, Rinaldi L, Brivio MF, Castellani D, de Eguileor M (2004) Muscle differentiation in tentacles of Sepia officinalis (Mollusca) is regulated by muscle regulatory factors (MRF) related proteins. Dev Growth Differ 46:83-95

Grimaldi AM, Agnisola C, Fiorito G (2007) Using ultrasound to estimate brain size in the cephalopod Octopus vulgaris Cuvier in vivo. Brain Res 1183:66-73 
Grimaldi AM, Belcari P, Pagano E, Cacialli F, Locatello L (2013) Immune responses of Octopus vulgaris (Mollusca: Cephalopoda) exposed to titanium dioxide nanoparticles. J Exp Mar Biol Ecol. doi:10.1016/j.jembe.2013.02.018

Grimpe G (1928) Pflege, Behandlung und Zucht der Cephalopoden fur zoologische und physiologische Zwecke. In: Äberhalden E (ed) Handbuch Der Biologischen Arbeitsmethoden. Urban, Berlin, pp 331-402

Guerra A, Martinell X, González AF, Vecchione M, Gracia J, Martinell J (2007) A new noise detected in the ocean. J Mar Biol Assoc UK 87:1255-1256

Gunkel C, Lewbart GA (2008) Anesthesia and analgesia of invertebrates. In: Fish RE, Brown MJ, Danneman PJAA, Karas AZ (eds) Anesthesia and analgesia in laboratory animals, 2nd edn. Academic Press, San Diego, pp 535-545

Gutfreund Y, Flash T, Yarom Y, Fiorito G, Segev I, Hochner B (1996) Organization of octopus arm movements: a model system for studying the control of flexible arms. J Neurosci 16: 7297-7307

Gutfreund Y, Matzner H, Flash T, Hochner B (2006) Patterns of motor activity in the isolated nerve cord of the octopus arm. Biol Bull 211:212-222

Gutnick T, Byrne RA, Hochner B, Kuba M (2011a) Octopus vulgaris uses visual information to determine the location of its arm. Curr Biol 21:460-462

Gutnick T, Richter J, Hochner B, Kuba MJ (2011b) Inland closed system laboratories chances and challenges. J Shellfish Res 30:1005-1006

Gutowska MA, Melzner F, Langenbuch M, Bock C, Claireaux G, Portner HO (2010a) Acid-base regulatory ability of the cephalopod (Sepia officinalis) in response to environmental hypercapnia. J Comp Physiol B Biochem Syst Environ Physiol 180:323-335

Gutowska MA, Melzner F, Portner HO, Meier S (2010b) Cuttlebone calcification increases during exposure to elevated seawater $\mathrm{pCO}_{2}$ in the cephalopod Sepia officinalis. Mar Biol 157: $1653-1663$

Hague T, Florini M, Andrews PLR (2013) Preliminary in vitro functional evidence for reflex responses to noxious stimuli in the arms of Octopus vulgaris. J Exp Mar Biol Ecol. doi:10.1016/j. jembe.2013.02.016

Hall KC, Fowler AJ, Geddes MC (2007) Evidence for multiple year classes of the giant Australian cuttlefish Sepia apama in northern Spencer Gulf, South Australia. Rev Fish Biol Fish 17:367-384

Hanlon RT, Forsythe JW (1990a) Diseases of Mollusca: Cephalopoda. Diseases caused by microorganisms. In: Kinne O (ed) Diseases of marine animals. Introduction, Cephalopoda, Annelida, Crustacea, Chaetognatha, Echinodermata, Urochordata, vol 3. Biologische Anstalt, Hamburg, pp 23-46

Hanlon RT, Forsythe JW (1990b) Diseases of Mollusca: Cephalopoda. Structural abnormalities and neoplasia. In: Kinne O (ed) Diseases of marine animals. Introduction, Cephalopoda, Annelida, Crustacea, Chaetognatha, Echinodermata, Urochordata, vol 3. Biologische Anstalt, Hamburg, pp 203-228

Hanlon RT, Messenger JB (1996) Cephalopod behaviour. Cambridge University Press, Cambridge

Hanlon RT, Hixon RF, Hulet WH (1983) Survival, growth, and behavior of the loliginid squids Loligo plei, Loligo pealei, and Lolliguncula brevis (Mollusca, Cephalopoda) in closed sea-water systems. Biol Bull 165:637-685

Hanlon RT, Forsythe JW, Cooper KM, Dinuzzo AR, Folse DS, Kelly MT (1984) Fatal penetrating skin ulcers in laboratory-reared octopuses. J Invert Pathol 44:67-83

Hartmann B, Lee PN, Kang YY, Tomarev S, de Couet HG, Callaerts P (2003) Pax6 in the sepiolid squid Euprymna scolopes: evidence for a role in eye, sensory organ and brain development. Mech Dev 120:177-183
Hawkins P, Dennison N, Goodman G, Hetherington S, LlywelynJones S, Ryder K, Smith AJ (2011a) Guidance on the severity classification of scientific procedures involving fish: report of a Working Group appointed by the Norwegian Consensus-Platform for the Replacement, Reduction and Refinement of animal experiments (Norecopa). Lab Anim 45:219-224

Hawkins P, Morton DB, Burman O, Dennison N, Honess P, Jennings M, Lane S, Middleton V, Roughan JV, Wells S, Westwood K (2011b) A guide to defining and implementing protocols for the welfare assessment of laboratory animals. Eleventh report of the BVAAWF/FRAME/RSPCA/UFAW Joint Working Group on Refinement. Lab Anim 45:1-13

Hermosilla CA, Rocha F, Fiorito G, Gonzalez AF, Guerra A (2010) Age validation in common octopus Octopus vulgaris using stylet increment analysis. ICES J Mar Sci 67:1458-1463

Hochberg FG (1990) Diseases of Mollusca: Cephalopoda. Diseases caused by Protistans and Metazoans. In: Kinne O (ed) Diseases of marine animals.Introduction, Cephalopoda, Annelida, Crustacea, Chaetognatha, Echinodermata, Urochordata, vol 3. Biologische Anstalt, Hamburg, pp 47-202

Hochner B (2008) Octopuses. Curr Biol 18:R897-R898

Hochner B (2012) An embodied view of octopus neurobiology. Curr Biol 22:R887-R892

Hochner B, Brown ER, Langella M, Shomrat T, Fiorito G (2003) A learning and memory area in the octopus brain manifests a vertebrate-like long-term potentiation. J Neurophysiol 90:3547-3554

Hochner B, Shomrat T, Fiorito G (2006) The octopus: a model for a comparative analysis of the evolution of learning and memory mechanisms. Biol Bull 210:308-317

Hodgkin AL, Huxley AF (1952) A quantitative description of membrane current and its application to conduction and excitation in nerve. J Physiol 117:500-544

Horvath K, Angeletti D, Nascetti G, Carere C (2013) Invertebrate welfare: an overlooked issue. Annali dell'Istituto Superiore di Sanit 49:9-17

Houck BA (1982) Temporal spacing in the activity patterns of three Hawaiian shallow-water octopus. Nautilus 96:152-156

Hu MY, Tseng YC, Stumpp M, Gutowska MA, Kiko R, Lucassen M, Melzner F (2011) Elevated seawater $\mathrm{pCO}_{2}$ differentially affects branchial acid-base transporters over the course of development in the cephalopod Sepia officinalis. Am J Physiol Regul Integr Comp Physiol 300:R1100-R1114

Huffard CL (2013) Cephalopod neurobiology: an introduction for biologists working in other model systems. Invert Neurosci 13. doi:10.1007/s10158-013-0147-z

Huffard CL, Caldwell RL, DeLoach N, Gentry DW, Humann P, MacDonald B, Moore B, Ross R, Uno T, Wong S (2008) Individually unique body color patterns in octopus (Wunderpus photogenicus) allow for photoidentification. PLoS One 3(11):e3732. doi:10.1371/journal.pone.0003732

Hurst JL, West RS (2010) Taming anxiety in laboratory mice. Nat Methods 7:825-U1516

Ibáñez CM, Keyl F (2010) Cannibalism in cephalopods. Rev Fish Biol Fish 20:123-136

Ikeda Y, Kobayashi M (2010) Statolith growth of juvenile oval squid Sepioteuthis lessoniana (Cephalopoda: Loliginidae) with special reference to ambient thermal condition. Mar Biol Res 6:485-495

Ikeda Y, Sugimoto C, Yonamine H, Oshima Y (2009) Method of ethanol anaesthesia and individual marking for oval squid (Sepioteuthis lessoniana Ferussac, 1831 in Lesson 1830-1831). Aquac Res 41:157-160

Jackson GD, Moltschaniwskyj NA (1999) Analysis of precision in statolith derived age estimates of the tropical squid Photololigo (Cephalopoda: Loliginidae). ICES J Mar Sci 56:221-227 
Jereb P, Roper CFE, Vecchione M (2005) Introduction. In: Cephalopods of the world. An annotated and illustrated catalogue of species known to date, vol 1. Chambered Nautiluses and Sepioids (Nautilidae, Sepiidae, Sepiolidae, Sepiadariidae, Idiosepiidae and Spirulidae). FAO species catalogue for fishery purposes. FAO Fisheries Synopsis, Rome, pp 1-13

Josef N, Amodio P, Fiorito G, Shashar N (2012) Camouflaging in a complex environment. Octopuses use specific features of their surroundings for background matching. PLoS One 7:e37579

Karson MA, Boal JG, Hanlon RT (2003) Experimental evidence for spatial learning in cuttlefish (Sepia officinalis). J Comp Psychol 117:149-155

Kier WM (1982) The functional-morphology of the musculature of squid (Loliginidae) arms and tentacles. J Morphol 172:179-192

Kier WM (1985) The musculature of squid arms and tentaclesultrastructural evidence for functional differences. J Morphol 185:223-239

Kier WM (1991) Squid cross-striated muscle-the evolution of a specialized muscle-fiber type. Bull Mar Sci 49:389-403

Kier WM, Schachat FH (2008) Muscle specialization in the squid motor system. J Exp Biol 211:164-169

Kier WM, Smith KK (1985) Tongues, tentacles and trunks-the biomechanics of movement in muscular-hydrostats. Zool J Linn Soc 83:307-324

Kier WM, Stella MP (2007) The arrangement and function of octopus arm musculature and connective tissue. J Morphol 268:831-843

Kier WM, VanLeeuwen JL (1997) A kinematic analysis of tentacle extension in the squid Loligo pealei. J Exp Biol 200:41-53

Kier WM, Smith KK, Miyan JA (1989) Electromyography of the fin musculature of the cuttlefish Sepia officinalis. J Exp Biol 143:17-31

Kilkenny C, Browne WJ, Cuthill IC, Emerson M, Altman DG (2010) Improving bioscience research reporting: the ARRIVE guidelines for reporting animal research. PLoS Biol 8:e1000412

King AJ, Adamo SA (2006) The ventilatory, cardiac and behavioural responses of resting cuttlefish (Sepia officinalis L.) to sudden visual stimuli. J Exp Biol 209:1101-1111

Kröger B, Vinther J, Fuchs D (2011) Cephalopod origin and evolution: a congruent picture emerging from fossils, development and molecules. BioEssays 33:602-613

Kuba MJ, Byrne RA, Meisel DV, Mather JA (2006) When do octopuses play? Effects of repeated testing, object type, age, and food deprivation on object play in Octopus vulgaris. J Comp Psychol 120:184-190

Lacoue-Labarthe T, Warnau A, Oberhansli F, Teyssie JL, Koueta N, Bustamante P (2008) Differential bioaccumulation behaviour of $\mathrm{Ag}$ and Cd during the early development of the cuttlefish Sepia officinalis. Aquat Toxicol 86:437-446

Lacoue-Labarthe T, Martin S, Oberhansli F, Teyssie JL, Jeffree R, Gattuso JP, Bustamante P (2012) Temperature and $\mathrm{pCO}_{2}$ effect on the bioaccumulation of radionuclides and trace elements in the eggs of the common cuttlefish, Sepia officinalis. J Exp Mar Biol Ecol 413:45-49

Lage S, Raimundo J, Brotas V, Costa PR (2012) Detection and subcellular distribution of the amnesic shellfish toxin, domoic acid, in the digestive gland of Octopus vulgaris during periods of toxin absence. Mar Biol Res 8:784-789

Lane FW (1960) Kingdom of the octopus; the life history of the Cephalopoda. Sheridan House, New York

Lange MM (1920) On the regeneration and finer structure of the arms of the cephalopods. J Exp Zool 31:1-57

Langridge KV, Broom M, Osorio D (2007) Selective signalling by cuttlefish to predators. Curr Biol 17:R1044-R1045

Larson SE, Anderson RC (2010) Fecal hormones measured within giant pacific octopuses Enteroctopus dofleini. J Aquat Anim Health 22:152-157
Laschi C, Cianchetti M, Mazzolai B, Margheri L, Follador M, Dario P (2012) Soft robot arm inspired by the octopus. Adv Robot 26:709-727

Le Goff R, Gauvrit E, Du Sel GP, Daguzan J (1998) Age group determination by analysis of the cuttlebone of the cuttlefish Sepia officinalis L. in reproduction in the Bay of Biscay. J Mollusc Stud 64:183-193

Lee PN, Callaerts P, de Couet HG, Martindale MQ (2003) Cephalopod Hox genes and the origin of morphological novelties. Nature 424:1061-1065

Lee PN, Callaerts P, de Couet HG (2009) The embryonic development of the Hawaiian bobtail squid (Euprymna scolopes). Cold Spring Harb Protoc 11:pdb.ip77

Lei SH, Zhang XM, Liu SL, Chen SQ (2012) Effects of temperature fluctuations on cuttlebone formation of cuttlefish Sepia esculenta. Chin J Oceanol Limnol 30:547-553

Lewbart GA, Mosley C (2012) Clinical anesthesia and analgesia in invertebrates. J Exot Pet Med 21:59-70

Lima PA, Nardi G, Brown ER (2003) AMPA/kainate and NMDA-like glutamate receptors at the chromatophore neuromuscular junction of the squid: role in synaptic transmission and skin patterning. Eur J Neurosci 17:507-516

Locatello L, Fiorito G, Finos L, Rasotto MB (2013) Behavioural and immunological responses to an immune challenge in Octopus vulgaris. Physiol Behav 122:93-99

Loe PR, Florey E (1966) The distribution of acetylcholine and cholinesterase in the nervous system and in innervated organs of Octopus dofleini. Comp Biochem Physiol 17:509-522

Loi PK, Tublitz NJ (2000) Roles of glutamate and FMRFamiderelated peptides at the chromatophore neuromuscular junction in the cuttlefish, Sepia officinalis. J Comp Neurol 420:499-511

Louhimies S (2011) Revised EU Legislation on the Protection of Animals Used for Scientific Purposes Directive 2010/63/EU. J Shellfish Res 30:1011

Lourenco HM, Anacleto P, Afonso C, Ferraria V, Martins MF, Carvalho ML, Lino AR, Nunes ML (2009) Elemental composition of cephalopods from Portuguese continental waters. Food Chem 113:1146-1153

Lucero MT, Gilly WF (1995) Physiology of squid olfaction. In: Abbott NJ, Williamson R, Maddock L (eds) Cephalopod neurobiology: neuroscience studies in squid, octopus and cuttlefish. Oxford University Press, Oxford, pp 521-534

Mackie GO (2008) Immunostaining of peripheral nerves and other tissues in whole mount preparations from hatchling cephalopods. Tissue Cell 40:21-29

Magee B, Elwood RW (2013) Shock avoidance by discrimination learning in the shore crab (Carcinus maenas) is consistent with a key criterion for pain. J Exp Biol 216:353-358

Malham SK, Coulson CL, Runham NW (1998a) Effects of repeated sampling on the haemocytes and haemolymph of Eledone cirrhosa (Lam.). Comp Biochem Physiol Part A Mol Integr Physiol 121:431-440

Malham SK, Runham RW, Secombes CJ (1998b) Lysozyme and antiprotease activity in the lesser octopus Eledone cirrhosa (Lam.) (Cephalopoda). Dev Comp Immunol 22:27-37

Malham SK, Lacoste A, Gelebart F, Cueff A, Poulet SA (2002) A first insight into stress-induced neuroendocrine and immune changes in the octopus Eledone cirrhosa. Aquat Living Resour 15:187-192

Margheri L, Mazzolai B, Dario P, Laschi C (2011a) A bioengineering approach for in vivo measurements of the octopus arms. J Shellfish Res 30:1012

Margheri L, Ponte G, Mazzolai B, Laschi C, Fiorito G (2011b) Noninvasive study of Octopus vulgaris arm morphology using ultrasound. J Exp Biol 214:3727-3731

Margheri L, Laschi C, Mazzolai B (2012) Soft robotic arm inspired by the octopus: I. From biological functions to artificial requirements. Bioinspir Biomim 7:025004 
Mather JA (1998) How do octopuses use their arms? J Comp Psychol 112:306-316

Mather JA (2008) Cephalopod consciousness: behavioural evidence. Conscious Cogn 17:37-48

Mather JA, Anderson RC (1999) Exploration, play, and habituation in octopuses (Octopus dofleini). J Comp Psychol 113:333-338

Mather JA, Anderson RC (2007) Ethics and invertebrates: a cephalopod perspective. Dis Aquat Org 75:119-129

Mattiello T, Fiore G, Brown ER, d'Ischia M, Palumbo A (2010) Nitric oxide mediates the glutamate-dependent pathway for neurotransmission in Sepia officinalis chromatophore organs. J Biol Chem 285:24154-24163

Mattiello T, Costantini M, Di Matteo B, Livigni S, Andouche A, Bonnaud L, Palumbo A (2012) The dynamic nitric oxide pattern in developing cuttlefish Sepia officinalis. Dev Dyn 241:390-402

Mazzolai B, Margheri L, Cianchetti M, Dario P, Laschi C (2012) Soft-robotic arm inspired by the octopus: II. From artificial requirements to innovative technological solutions. Bioinspir Biomim 7:025005

McFall-Ngai MJ (1994) Animal-bacterial interactions in the early life history of marine invertebrates: the Euprymna scolopes-Vibrio fischeri symbiosis. Am Zool 34:554-561

McFall-Ngai MJ, Nyholm SV, Castillo MG (2010) The role of the immune system in the initiation and persistence of the Euprymna scolopes-Vibrio fischeri symbiosis. Semin Immunol 22:48-53

Meisel DV, Byrne RA, Kuba M, Griebel U, Mather JA (2003) Circadian rhythms in Octopus vulgaris. Berliner Paläobiol Abh 3:171-177

Meisel DV, Byrne RA, Kuba M, Mather J, Ploberger W, Reschenhofer E (2006) Contrasting activity patterns of two related octopus species, Octopus macropus and Octopus vulgaris. J Comp Psychol 120:191-197

Messenger JB (1996) Neurotransmitters of cephalopods. Invertbr Neurosci 2:95-114

Messenger JB (2001) Cephalopod chromatophores: neurobiology and natural history. Biol Rev 76:473-528

Messenger JB, Nixon M, Ryan KP (1985) Magnesium chloride as an anaesthetic for cephalopods. Comp Biochem Physiol C CompPharmacol 82:203-205

Moltschaniwskyj N, Hall K, Marian J, Nishiguchi M, Sakai M, Shulman D, Sinclair B, Sinn D, Staudinger M, Van Gelderen R, Villanueva R, Warnke K (2007) Ethical and welfare considerations when using cephalopods as experimental animals. Rev Fish Biol Fish 17:455-476

Mooney TA, Lee WJ, Hanlon RT (2010) Long-duration anesthetization of squid (Doryteuthis pealeii). Mar Freshwter Behav Physiol 43:297-303

Moreno H, Choi S, Yu E, Brusco J, Avila J, Moreira J, Sugimori M, Llinas RR (2011) Blocking effects of human tau on squid giant synapse transmission and its prevention by T-817 MA. Front Synaptic Neurosci 3(3). doi:10.3389/fnsyn.2011.00003

Morton DB, Griffiths PHM (1985) Guidelines on the recognition of pain, distress and discomfort in experimental-animals and an hypothesis for assessment. Vet Rec 116:431-436

Muntz WRA (1995) Giant octopuses and squid from Pliny to the Rev. Moses Harvey. Arch Nat Hist 22:1-28

Napoleao P, Pirtheiro T, Reis CS (2005) Elemental characterization of tissues of Octopus vulgaris along the Portuguese coast. Sci Total Environ 345:41-49

Navet S, Bassaglia Y, Baratte S, Martin M, Bonnaud L (2008) Somatic muscle development in Sepia officinalis (CephalopodaMollusca): a new role for NK4. Dev Dyn 237:1944-1951

Navet S, Andouche A, Baratte S, Bonnaud L (2009) Shh and Pax6 have unconventional expression patterns in embryonic morphogenesis in Sepia officinalis (Cephalopoda). Gene Expr Patterns 9:461-467
Neill D (2010) The effect of the Crustastun on nerve activity in crabs and lobsters. University of Scotland, Glasgow

Nixon M, Young JZ (2003) The brains and lives of cephalopods. Oxford University Press, Oxford

Norman M (2000) Cephalopods, a world guide. ConchBooks, Hackenheim

Nosengo N (2011) European directive gets its tentacles into octopus research. Nat News. doi:10.1038/news.2011.229

Nyholm SV, Graf J (2012) Knowing your friends: invertebrate innate immunity fosters beneficial bacterial symbioses. Nat Rey Microbiol 10:815-827

Nyholm SV, Stewart JJ, Ruby EG, McFall-Ngai MJ (2009) Recognition between symbiotic Vibrio fischeri and the haemocytes of Euprymna scolopes. Environ Microbiol 11:483-493

Oestmann DJ, Scimeca JM, Forsythe J, Hanlon R, Lee P (1997) Special considerations for keeping cephalopods in laboratory facilities. Contemp Top Lab Anim Sci 36:89-93

Osorio D, Zylinski S (2011) Cuttlefish vision in camouflage. J Shellfish Res 30:1015

Packard A (1972) Cephalopods and fish: the limits of convergence. Biol Rev 47:241-307

Pagano E, Ponte G, Andrews PLR, Fiorito G (2011) A comparative analysis of different anaesthetics in octopus: towards true anaesthesia? J Shellfish Res 30:1016

Palumbo A, Di Cosmo A, Poli A, Di Cristo C, d' Ischia M (1999) A calcium/calmodulin-dependent nitric oxide synthase, NMDAR2/ 3 receptor subunits, and glutamate in the CNS of the cuttlefish Sepia officinalis: localization in specific neural pathways controlling the inking system. J Neurochem 73:1254-1263

Paredes I, Rietjens IMCM, Vieites JM, Cabado AG (2011) Update of risk assessments of main marine biotoxins in the European Union. Toxicon 58:336-354

Pascual S, Hochberg FG (1996) Marine parasites as biological tags of cephalopod hosts. Parasitol Today 12:324-327

Pascual S, Rocha F, Guerra A (2006) Gross lesions in the Hubb octopus Octopus hubbsorum. Mar Biol Res 2:420-423

Pascual S, González AF, Guerra A (2010) Coccidiosis during octopus senescence: preparing for parasite outbreak. Fish Res 106:160-162

Pereira P, Raimundo J, Vale C, Kadar E (2009) Metal concentrations in digestive gland and mantle of Sepia officinalis from two coastal lagoons of Portugal. Sci Total Environ 407:1080-1088

Perez JAA, Odor RK, Beck P, Dawe EG (1996) Evaluation of gladius dorsal surface structure for age and growth studies of the shortfinned squid, Illex illecebrosus (Teuthoidea: Ommastrephidae). Can J Fish Aquat Sci 53:2837-2846

Pernice M, Boucher J, Boucher-Rodoni R, Joannot P, Bustamante P (2009) Comparative bioaccumulation of trace elements between Nautilus pompilius and Nautilus macromphalus (Cephalopoda: Nautiloidea) from Vanuatu and New Caledonia. Ecotoxicol Environ Saf 72:365-371

Poirier R, Chichery R, Dickel L (2004) Effects of rearing conditions on sand digging efficiency in juvenile cuttlefish. Behav Proc 67:273-279

Polglase JL, Bullock AM, Roberts RJ (1983) Wound-healing and the hemocyte response in the skin of the lesser octopus Eledone cirrhosa (Mollusca, Cephalopoda). J Zool 201:185-204

Ponte G (2012). Distribution and preliminary functional analysis of some modulators in the cephalopod mollusc Octopus vulgaris. $\mathrm{PhD}$ thesis, Università della Calabria, Italy; Stazione Zoologica Anton Dohrn, Napoli, Italy

Ponte G, Fiorito G (2011) Research efforts on cephalopods: an overview of the last 5 years. J Shellfish Res 30:1017-1018

Ponte G, Fiorito G (2013) A special issue on cephalopod biology: contributions of a community to the advancements of the biology of cephalopods. J Exp Mar Biol Ecol. doi:10.1016/j.jembe.2013. 02.005 
Ponte G, Dröscher A, Fiorito G (2013) Fostering cephalopod biology research: past and current trends and topics. Invertebr Neurosci 13:1-9

Rader BA, Nyholm SV (2012) Host/microbe interactions revealed through "omics" in the symbiosis between the Hawaiian bobtail squid Euprymna scolopes and the bioluminescent bacterium Vibrio fischeri. Biol Bull 223:103-111

Raimundo J, Vale C (2008) Partitioning of $\mathrm{Fe}, \mathrm{Cu}, \mathrm{Zn}, \mathrm{Cd}$, and $\mathrm{Pb}$ concentrations among eleven tissues of Octopus vulgaris from the Portuguese coast. Ciencias Marinas 34:297-305

Raimundo J, Pereira P, Vale C, Caetano M (2005) Fe, Zn, Cu and Cd concentrations in the digestive gland and muscle tissues of Octopus vulgaris and Sepia officinalis from two coastal areas in Portugal. Ciencias Marinas 31:243

Raimundo J, Vale C, Caetano M, Cesario R, Moura I (2009) Total lead and its stable isotopes in the digestive gland of Octopus vulgaris as a fingerprint. Aquat Biol 6:25-30

Raimundo J, Costa PM, Vale C, Costa MH, Moura I (2010a) DNA damage and metal accumulation in four tissues of feral Octopus vulgaris from two coastal areas in Portugal. Ecotoxicol Environ Saf 73:1543-1547

Raimundo J, Vale C, Duarte R, Moura I (2010b) Association of Zn, $\mathrm{Cu}, \mathrm{Cd}$ and $\mathrm{Pb}$ with protein fractions and sub-cellular partitioning in the digestive gland of Octopus vulgaris living in habitats with different metal levels. Chemosphere 81:1314-1319

Raya CP, Jurado-Ruzafa A, Bartolomé A, Duque V, Carrasco MN, Fraile-Nuez E (2013) Age of spent Octopus vulgaris and stress mark analysis using beaks of wild individuals. Hydrobiologia. doi:10.1007/s10750-013-1602-x

Reimschuessel R, Stoskopf MK (1990) Octopus automutilation syndrome. J Invertebr Pathol 55:394-400

Robertson JD, Bonaventura J, Kohm AP (1994) Nitric oxide is required for tactile learning in Octopus vulgaris. Proc R Soc Lond B 256:269-273

Robertson JD, Bonaventura J, Kohm A (1995) Nitric-oxide synthase inhibition blocks octopus touch learning without producing sensory or motor dysfunction. Proc R Soc Lond B 261:167-172

Robertson JD, Bonaventura J, Kohm A, Hiscat M (1996) Nitric oxide is necessary for visual learning in Octopus vulgaris. Proc R Soc Lond B 263:1739-1743

Rocha F, Guerra A, Gonzalez AF (2001) A review of reproductive strategies in cephalopods. Biol Rev 76:291-304

Rohrbach B, Schmidtberg H (2006) Sepia arms and tentacles: model systems for studying the regeneration of brachial appendages. Vie Milieu 56:175-190

Rosa R, Pimentel MS, Boavida-Portugal J, Teixeira T, Trübenbach K, Diniz M (2012) Ocean warming enhances malformations, premature hatching, metabolic suppression and oxidative stress in the early life stages of a keystone squid. PLoS One 7:e38282

Russell WMS, Burch RL (1959) The principles of humane experimental technique. Methuen, London

Sanders GD (1975) The cephalopods. In: Corning WC, Dyal JA, Willows AOD (eds) Invertebrate learning. Cephalopods and echinoderms. Plenum Press, New York, pp 1-101

Sanders GD, Young JZ (1974) Reappearance of specific colour patterns after nerve regeneration in Octopus. Proc R Soc Lond Ser B Biol Sci 186:1-11

Scheinker V, Fiore G, Di Cristo C, Di Cosmo A, d'Ischia M, Enikolopov G, Palumbo A (2005) Nitric oxide synthase in the nervous system and ink gland of the cuttlefish Sepia officinalis: molecular cloning and expression. Biochem Biophys Res Commun 338:1204-1215

Seixas S, Pierce G (2005) Bioaccumulation of lead, calcium and strontium and their relationships in the octopus Octopus vulgaris. Water Air Soil Pollut 163:137-152
Seixas S, Bustamante P, Pierce GJ (2005) Interannual patterns of variation in concentrations of trace elements in arms of Octopus vulgaris. Chemosphere 59:1113-1124

Semedo M, Reis-Henriques MA, Rey-Salgueiro L, Oliveira M, Delerue-Matos C, Morais S, Ferreira M (2012) Metal accumulation and oxidative stress biomarkers in octopus (Octopus vulgaris) from Northwest Atlantic. Sci Total Environ 433:230-237

Semmens JM, Pecl GT, Villanueva R, Jouffre D, Sobrino I, Wood JB, Rigby PR (2004) Understanding octopus growth: patterns, variability and physiology. Mar Freshwater Res 55:367-377

Sen H, Tanrikul TT (2009) Efficacy of 2-phenoxyethanol as an anaesthetic for the musky octopus, Eledone moschata (Lamarck 1799) (Cephalopoda: Octopodidae). Turk J Vet Anim Sci 33:463-467

Seol DW, Lee J, Im SY, Park IS (2007) Clove oil as an anaesthetic for common octopus (Octopus minor, Sasaki). Aquac Res 38:45-49

Sereni E, Young JZ (1932) Nervous degeneration and regeneration in cephalopods. Pubbl Staz Zool Napoli 12:173-208

Shigeno S, Yamamoto M (2002) Organization of the nervous system in the pygmy cuttlefish, Idiosepius paradoxus Ortmann (Idiosepiidae, Cephalopoda). J Morphol 254:65-80

Shigeno S, Kidokoro H, Tsuchiya K, Segawa S, Yamamoto M (2001a) Development of the brain in the oegopsid squid, Todarodes pacificus: an atlas up to the hatching stage. Zool Sci 18:527-541

Shigeno S, Tsuchiya K, Segawa S (2001b) Embryonic and paralarval development of the central nervous system of the loliginid squid Sepioteuthis lessoniana. J Comp Neurol 437:449-475

Shigeno S, Parnaik R, Ragsdale CW (2008a) Octopus brains: the molecular architecture of functionally identified neural systems (Mollusca). J Morphol 269:1466-1467

Shigeno S, Sasaki T, Moritaki T, Kasugai T, Vecchione M, Agata K (2008b) Evolution of the cephalopod head complex by assembly of multiple molluscan body parts: evidence from Nautilus embryonic development. J Morphol 269:1-17

Shomrat T, Zarrella I, Fiorito G, Hochner B (2008) The octopus vertical lobe modulates short-term learning rate and uses LTP to acquire long-term memory. Curr Biol 18:337-342

Shomrat T, Feinstein N, Klein M, Hochner B (2010) Serotonin is a facilitatory neuromodulator of synaptic transmission and "reinforces" long-term potentiation induction in the vertical lobe of Octopus vulgaris. Neuroscience 169:52-64

Shomrat T, Graindorge N, Bellanger C, Fiorito G, Loewenstein Y, Hochner B (2011) Alternative sites of synaptic plasticity in two homologous "fan-out fan-in" learning and memory networks. Curr Biol 21:1773-1782

Sikes RS, Gannon WL (2011) Guidelines of the American Society of Mammalogists for the use of wild mammals in research. J Mammal 92:235-253

Smith PT (2008) Cyanobacterial toxins in aquaculture. In: Botana LM (ed) Seafood and freshwater toxins: pharmacology, physiology, and detection, 2nd edn. CRC Press, Boca Raton, pp 787-806

Smith JL, Boyer GL, Zimba PV (2008) A review of cyanobacterial odorous and bioactive metabolites: impacts and management alternatives in aquaculture. Aquaculture 280:5-20

Smith JA, Andrews PLR, Hawkins P, Louhimies S, Ponte G, Dickel L (2013) Cephalopod research and EU Directive 2010/63/EU: requirements, impacts and ethical review processes. J Exp Mar Biol Ecol. doi:10.1016/j.jembe.2013.02.009

Song LJ, Liu YH, Yu Y, Duan X, Qi SN, Liu YB (2012) Shh signaling guides spatial pathfinding of raphespinal tract axons by multidirectional repulsion. Cell Res 22:697-716

Storelli MM, Barone G, Marcotrigiano GO (2005) Cadmium in cephalopod molluscs: implications for public health. J Food Prot 68:577-580 
Sumbre G, Gutfreund Y, Fiorito G, Flash T, Hochner B (2001) Control of octopus arm extension by a peripheral motor program. Science 293:1845-1848

Sumbre G, Fiorito G, Flash T, Hochner B (2005) Motor control of flexible octopus arms. Nature 433:595-596

Sumbre G, Fiorito G, Flash T, Hochner B (2006) Octopuses use a human-like strategy to control precise point-to-point arm movements. Curr Biol 16:767-772

Sykes A, Domingues PM, Márquez L, Andrade JP (2011) The effects of tank colours on the growth and survival of cuttlefish (Sepia officinalis, Linnaeus 1758) hatchlings and juveniles. Aquac Res 42:441-449

Sykes AV, Baptista FD, Goncalves RA, Andrade JP (2012) Directive 2010/63/EU on animal welfare: a review on the existing scientific knowledge and implications in cephalopod aquaculture research. Rev Aquac 4:142-162

Sykes A, Pereira D, Rodriguez C, Lorenzo A, Andrade JP (2013) Effects of increased tank bottom areas on cuttlefish (Sepia officinalis, L.) reproduction performance. Aquac Res 44:1017-1028

Tansey EM (1978) A histochemical study of the cephalopod brain. PhD University of Sheffield, UK

Tansey EM (1979) Neurotransmitters in the cephalopod brain. Comp Biochem Physiol Part C Pharmacol Toxicol Endocrinol 64:173-182

Toonen R (2003) Aquarium invertebrates: housing an octopus. Adv Aquarist 2 (online)

Tressler J, Maddox F, Goodwin E, Zhang Z, Tublitz N (2013) Arm regeneration in two species of cuttlefish Sepia officinalis and Sepia pharaonis. Invertebr Neurosci. doi:10.1007/s10158-0130159-8

Tricarico E, Borrelli L, Gherardi F, Fiorito G (2011) I know my neighbour: individual recognition in Octopus vulgaris. PLoS One 6(4):e18710. doi:10.1371/journal.pone.0018710

Tublitz NJ, Gaston MR, Loi PK (2006) Neural regulation of a complex behavior: body patterning in cephalopod molluscs. Integr Comp Biol 46:880-889

Vinogradova IM, Zajicek J, Gentile S, Brown ER (2002) Effect of glycine on synaptic transmission at the third order giant synapse of the squids Alloteuthis subulata and Loligo vulgaris. Neurosci Lett 325:42-46

Voipio H-M, Kaliste E, Hirsjärvi P, Nevalainen T, Ritskes-Hoitinga M (2004) Nordic-European workshop on ethical evaluation of animal experiments. Scand J Lab Anim Sci 31:251-266

Walker JJ, Longo N, Bitterman ME (1970) Octopus in laboratoryhandling, maintenance. Train Behav Res Methods Instrum $2: 15-18$

Wang D-Z (2008) Neurotoxins from marine dinoflagellates: a brief review. Mar Drugs 6:349-371

Watkins SM, Reich A, Fleming LE, Hammond R (2008) Neurotoxic shellfish poisoning. Mar Drugs 6:431-455

Wearmouth VJ, Durkin OC, Bloor I, McHugh M, Rundle J, Sims DW (2013) A method for long-term electronic tagging and tracking of juvenile and adult European common cuttlefish Sepia officinalis. J Exp Mar Biol Ecol. doi:10.1016/j.jembe.2013.02. 023

Wells MJ (1962) Brain and behaviour in cephalopods. Heinemann, London

Wells MJ (1978) Octopus: physiology and behaviour of an advanced invertebrate. Chapman and Hall, London

Wells MJ, Freeman NH, Ashburne M (1965) Some experiments on chemotactile sense of octopuses. J Exp Biol 43:553-563

Westermann B, Ruth P, Litzlbauer HD, Beck I, Beuerlein K, Schmidtberg H, Kaleta EF, Schipp R (2002) The digestive tract of Nautilus pompilius (Cephalopoda, Tetrabranchiata): an Xray analytical and computational tomography study on the living animal. J Exp Biol 205:1617-1624

Williamson R (1986) Efferent activity in the octopus statocyst nerves. J Comp Physiol A Neuroethol Sens Neur Behav Physiol 158:125-132

Williamson R (1989) Electrophysiological evidence for cholinergic and catecholaminergic efferent transmitters in the statocyst of octopus. Comp Biochem Physiol Part C Pharmacol Toxicol Endocrinol 93:23-27

Williamson R (1995) A sensory basis for orientation in cephalopods. J Mar Biol Assoc UK 75:83-92

Williamson R, Chrachri A (2004) Cephalopod neural networks. Neurosignals 13:87-98

Wodinsky J (1977) Hormonal inhibition of feeding and death in octopus - control by optic gland secretion. Science 198:948-951

Wollesen T, Loesel R, Wanninger A (2008) FMRFamide-like immunoreactivity in the central nervous system of the cephalopod mollusc, Idiosepius notoides. Acta Biol Hung 59:111-116

Wollesen T, Loesel R, Wanninger A (2009) Pygmy squids and giant brains: mapping the complex cephalopod CNS by phalloidin staining of vibratome sections and whole-mount preparations. J Neurosci Methods 179:63-67

Wollesen T, Cummins SF, Degnan BM, Wanninger A (2010a) FMRFamide gene and peptide expression during central nervous system development of the cephalopod mollusk, Idiosepius notoides. Evol Dev 12:113-130

Wollesen T, Degnan BM, Wanninger A (2010b) Expression of serotonin (5-HT) during CNS development of the cephalopod mollusk, Idiosepius notoides. Cell Tissue Res 342:161-178

Wollesen T, Sukhsangchan C, Seixas P, Nabhitabhata J, Wanninger A (2012) Analysis of neurotransmitter distribution in brain development of benthic and pelagic octopod cephalopods. J Morphol 273:776-790

Workman P, Aboagye EO, Balkwill F, Balmain A, Bruder G, Chaplin DJ, Double JA, Everitt J, Farningham DAH, Glennie MJ, Kelland LR, Robinson V, Stratford IJ, Tozer GM, Watson S, Wedge SR, Eccles SA, Navaratnam V, Ryder S (2010) Guidelines for the welfare and use of animals in cancer research. Br J Cancer 102:1555-1577

Young JZ (1938) The functioning of the giant nerve fibres of the squid. J Exp Biol 15:170-185

Young JZ (1985) Cephalopods and neuroscience. Biol Bull (Woods Hole) 168:153-158

Young JZ (1991) Computation in the learning system of cephalopods. Biol Bull 180:200-208

Young JZ (1995) Multiple matrices in the memory system of Octopus. In: Abbott JN, Williamson R, Maddock L (eds) Cephalopod neurobiology. Oxford University Press, Oxford, pp 431-443

Zeeh KM, Wood JB (2009) Impact of visible implant elastomer tags on the growth rate of captive Caribbean reef squid Sepioteuthis sepioidea. Fish Res 95:362-364

Zullo L, Hochner B (2011) A new perspective on the organization of an invertebrate brain. Commun Integr Biol 4:26-29

Zullo L, Sumbre G, Agnisola C, Flash T, Hochner B (2009) Nonsomatotopic organization of the higher motor centers in octopus. Curr Biol 19:1632-1636

Zylinski S, How MJ, Osorio D, Hanlon RT, Marshall NJ (2011) To be seen or to hide: visual characteristics of body patterns for camouflage and communication in the Australian giant cuttlefish Sepia apama. Am Nat 177:681-690 